\title{
Strategic Principles for Smart City Development: A Multiple Case Study Analysis of European Best Practices
}

\begin{abstract}
Recent studies reveal a deep-rooted division in research on smart cities, which surfaces as a set of dichotomies that question whether smart city development should be based on a: (1) technology-led or holistic strategy; (2) double or quadruple-helix model of collaboration; (3) top-down or bottom-up approach; (4) mono-dimensional or integrated intervention logic. These dichotomies generate a critical knowledge gap because they suggest divergent hypotheses on what principles need to be considered when implementing strategies for enabling smart city development. This paper starts filling such a gap by reporting on the findings of a multiple case study analysis which is conducted into European best practices. In meeting this aim, four European cities considered to be leaders in the field of smart city development are analyzed to test the validity of the hypotheses emerging from each dichotomy. These cities are Amsterdam, Barcelona, Helsinki and Vienna. The results of this best practice analysis offer a series of critical insights into what strategic principles drive smart city development in Europe and generate scientific knowledge which helps to overcome the dichotomous nature of smart city research.
\end{abstract}

Keywords: smart city; urban development; urban innovation; case study research; best practices; strategic principles 


\section{Introduction}

Disagreements over the status of smart city development were first reported on by Hollands (2008). After reviewing the literature on smart cities produced between 1990 and 2007, his research identified and compared a number of attempts to formulate a definition of the smart city, capturing both a lack of clarity and absence of any agreement on how this concept is understood by the scientific community. According to Albino et al. (2015) and Meijer and Bolivar (2016), despite the intervening growth of research on smart city development, these disagreements on what such a development represents are still firmly entrenched in the scientific literature. The validity of this claim has been proved by Mora et al. $(2017 ; 2018 a ; 2018 b)$ and Komninos and Mora (2018), with a series of bibliometric analyses that reveal the presence of a deep-rooted division in the research on smart cities: a division which surfaces as four dichotomies questioning how smart city development should be approached.

The research from Mora et al. (2017; 2018a; 2018b) and Komninos and Mora (2018) demonstrates that these dichotomies are significant, because they generate divergent hypotheses on what principles drive smart city development and the strategies assembled to enable it. As they note, this division introduces uncertainty over the implementation of strategies for supporting smart city development and reveal a critical knowledge gap that this paper starts filling by means of a multiple case study analysis. The validity of the strategic principles for smart city development that each dichotomy suggests is tested in Europe, by comparing four cities considered to be leading examples of smart cities. These cities are Amsterdam, Barcelona, Helsinki and Vienna, which are respectively located in the Netherlands, Spain, Finland and Austria.

The paper is split in fourfive main sections and begins by setting out the dichotomous nature of smart city research. The first section presents the four dichotomies and the divergent strategic principles that they propose by reviewing the most recent literature on smart cities ${ }^{1}$. This review serves to reveal both the division in research on smart cities and rationale for this study into the dichotomous nature of the strategic principles such a research currently rests on. The second and third sections respectively report on the methodology used to conduct the case study analysis and the results obtained, explaining how each city has approached smart city development in relation to the four dichotomies. The results of this analysis make it possible to conclude with a number of recommendations that address: (1) which strategic principles European cities should take into consideration in order to support smart city development; (2) how future research on smart cities can continue to produce the scientific knowledge that is necessary to fully overcome the knowledge gap that the dichotomous nature of smart city research has generated. These recommendations are discussed in the last two sections of the paper.

\section{The dichotomous nature of research on smart cities: a literature review}

Researchers' interest in understanding how to effectively enable smart city development has been growing over the years, along with the number of cities seeking to become smart by exploiting the opportunities that ICT-related solutions offer to meet urban challenges. This growth trend can be captured by comparing the data provided by Singh (2010), Lee and Hancock (2012) and Manville et al. (2014).

According to the consulting firm Frost \& Sullivan, only 41 cities were promoting smart city development in 2010 (Singh 2010). However, when this mapping exercise was repeated by Yonsei University in 2012, the figure had significantly changed. In two years, the number of cities increased from 41 to 143 (Lee and Hancock 2012) and most of the additional cases

\footnotetext{
${ }^{1}$ This literature review extends the discussion on the dichotomous nature of smart city research proposed by Mora et al. (2018a; 2018c).
} 
were found in Europe, Asia and North America. This growth trend was also confirmed by RAND Corporation, with a study conducted in 2014 on behalf of the European Parliament. By limiting the search for smart city cases to the European Union's Member States, about 500 cities were found in the process of assembling smart city development strategies (Manville et al. 2014).

Strategies for smart city development can be found all over the world and researchers have made significant efforts in investigating their design and implementation processes. For example, Bakici et al. (2013), Zygiaris (2013), Bolici and Mora (2015), Grimaldi and Fernandez (2017), Cardullo and Kitchin (2017), Coletta et al. (2017), Cowley et al. (2017), Taylor Buck and White (2017) and van Winden and van den Buuse (2017) all report on the smart city development promoted in Europe by focusing attention on the cities of Amsterdam, Barcelona, Birmingham, Bristol, Dublin, Edinburgh, Glasgow, London, Peterborough, Manchester and Milton Keynes. Vanolo (2014) describes the commitment of Italy to smart city development and provides some theoretical reflections on the approach adopted by the cities of Bari, Bologna, Turin, Genoa, Milan and Naples. Genoa is also analyzed by Grossi and Pianezzi (2017) and Dameri (2014).

Lee et al. (2014) compare the strategies of San Francisco and Seoul, and further studies focusing attention on Asian and American smart city cases are published by Alawadhi et al. (2012), Shwayri (2013), Fietkiewicz and Stock (2015), Wiig (2015a; 2015b), Alvin Yau et al. (2016), Cugurullo (2016), Lee et al. (2016), Schreiner (2016) and Gupta and Hall (2017). These publications explore the experiences of Dholera, Masdar, Songdo, Philadelphia, Rio de Janeiro, Seattle, Quebec City, Mexico City, Tokyo, Yokohama, Osaka, Singapore, Kyoto and Kuala Lumpur.

In addition, research by Kitchin (2015) and Paroutis et al. (2014) reports on the IBM's Smarter Planet initiative and its Smarter City Challenge, which invites cities to compete for IBM's "consultancy, technical assistance and grants aimed at developing technological solutions" for the urban environment (Kitchin 2015). This challenge was launched in 2010 and the cities that have already been selected and included in the initiative exceeds $130^{2}$.

Additional case study analyses can be found in the following publications:

- Komninos (2011) selects Amsterdam, Hong Kong and Milton Keynes to describe three different approaches to smart city development in which the local communities' intellectual capital and information technologies are combined;

- Leydesdorff and Deakin (2011) deploy the triple-helix model to analyze the smart city development strategies of Montreal and Edinburgh;

- Alcatel-Lucent compares more than 50 smart city cases (Anderson et al. 2012), and a similar research activity is also undertaken by Cisco Systems (2012) and ARUP (Buscher and Doody 2013);

- Angelidou (2014) proposes a typological classification of smart city development strategies which draws upon the analysis of Malta, New York City, Barcelona, Songdo IBD, Rio de Janeiro, Singapore and Thessaloniki;

- Datta (2015), Yu et al. (2016), Praharaj et al. (2017), Sharma and Rajput (2017) and Bansal et al. (2017) reflect upon the Indian approach to smart city development;

- Mora and Bolici $(2016 ; 2017)$ compare Amsterdam and Barcelona and build a step-bystep roadmap that describes the design and implementation process of smart city development strategies;

- Aina (2017) classifies and analyzes a number of smart city cases located in Saudi Arabia.

\footnotetext{
2 The list of cities selected by IBM in the framework of the Smarter Cities Challenge can be found on the official website of the initiative: https://www.smartercitieschallenge.org
} 
Despite this growing interest in smart cities and almost three decades of literature on the matter, research is still unable to clearly explain what needs to be done in order for urban environments to be successful when designing and implementing smart city development strategies. Recent studies from Mora et al. (2018a; 2018b) show the existence of five main development paths of smart cities, which overlap one another and generate uncertainty on how to deal with smart city development in real-life environments. These paths uncover strategic principles that are divergent in nature and make it difficult to establish whether smart city development should be approached by means of either a: (1) Technology-led or holistic strategy; (2) Double or quadruple-helix model of collaboration; (3) Top-down or bottom-up approach; (4) Mono-dimensional or integrated intervention logic. The questions arising from each dichotomy open up a knowledge gap that current research on smart cities is unable to overcome, and this can be easily demonstrated by examining the literature produced to date.

ICT companies like IBM, Cisco Systems, Siemens, ABB, Hitachi and Fujitsu suggest the introduction of loads of ICT solutions in urban infrastructures is the sole factor to consider in order to enable smart city development (Chen-Ritzo et al. 2009; Dirks and Keeling 2009; Dirks et al. 2009; 2010; Harrison et al. 2010; 2011; Brech et al. 2011; Cosgrove et al. 2011; Kehoe et al. 2011; Kohno et al. 2011; Katz and Ruano 2011; Kurebayashi et al. 2011; Paul et al. 2011; Ruano et al. 2011; Schaefer et al. 2011; Yoshikawa et al. 2011; Amato et al. 2012a; 2012b; ABB 2013; Siemens 2014; Tamai 2014).

However, a significant body of research considers this technology-led theory of supply-push solutions to be inadequate and unable to cope with the complexity of smart city development, because it promotes a utopian and technological deterministic interpretation of smart cities that serves nothing but the interests of companies working in the technology industry. The researchers raising objections to this interpretation call for a much more progressive and holistic vision that conceives smart cities not as technological fixes resulting from the agglomeration of ICT solutions in urban infrastructures, but as complex socio-technical systems in which technological development is aligned with human, social, cultural, economic and environmental factors (Hollands 2008; 2015; 2016; Bergvall-Kåreborn et al. 2009; Caragliu et al. 2011; Cugurullo 2013; 2016; Townsend 2013; Christopoulou et al. 2014; Deakin 2014b; Kitchin 2014; Komninos 2014; Luque-Ayala et al. 2014; Soderstrom et al. 2014; Viitanen and Kingston 2014; Carvalho 2015; Luque-Ayala and Marvin 2015; Concilio and Rizzo 2016; McNeill 2016; Niaros 2016; Pollio 2016; Scuotto et al. 2016; Sujata et al. 2016; Yigitcanlar 2016; Yigitcanlar and Lee 2014; Angelidou and Psaltoglou 2017; Ersoy 2017; Grossi and Pianezzi 2017; Mora et al. 2017; Selada 2017; Reddy Kummitha and Crutzen 2017).

As pointed out by Paroutis et al. (2014), Soderstrom et al. (2014), McNeill (2015; 2016), Pollio (2016) and Grossi and Pianezzi (2017), ICT companies also suggest smart city development strategies require a closed collaborative model in which the interaction is only between: (1) solution providers acting as consultants who offer their technological fixes; and (2) the local governments, which are persuaded to underpin smart city development by adopting such proprietary technologies. The double-helix structure of this collaborative model generates an entrepreneurial mode of governance where information technology corporations working in the market of smart city services become "the main providers of solutions to urban problems" (Pollio 2016: 515).

Leydesdorff and Deakin (2011), Baccarne et al. (2014a; 2014b), Dameri (2014; 2017), Deakin and Leydesdorff (2014), Kourtit et al. (2014), van Waart et al. (2016), Mora and Bolici (2016; 2017), Angelidou (2017), Gardner and Hespanhol (2017) and Selada (2017) all agree in suggesting that such a double-helix collaborative model does not provide the intellectual capital which is necessary to drive smart city development. Their research calls for a broader collaborative ecosystem in which the interests of governments, universities and industry are com- 
bined (triple-helix structure), along with those expressed by citizens and civil society organizations $^{3}$ (quadruple-helix structure ${ }^{4}$ ). According to this collaborative model, "different urban stakeholders (public, private and civic) [need to] engage in coalitions and innovate together" in order for smart cities development strategies to be successful (van Winden and van den Buuse 2017: 68).

The division in smart city research also surfaces when trying to establish whether the most suitable approach for supporting smart city development is top-down or bottom-up. This dualism is discussed in research by Ratti and Townsend (2011), Schuurman et al. (2012; 2016), Dameri (2013), Townsend (2013), Lee et al. (2014), Komninos (2014), Kitchin (2014), Breuer et al. (2014), Neirotti et al. (2014), Walravens (2015), Exner (2015), Gooch et al. (2015) and Mora and Bolici $(2016 ; 2017)$.

Top-down smart cities are understood to generate from the city government, which defines both a long-term vision and a strategic framework for the governance of smart city development. Bottom-up smart cities result instead from a deregulated process, self-organization and grassroots movements. Also, the bottom-up approach to smart city development puts civil society in the driving seat and calls for the direct involvement of citizens in the development of the ICT solutions needed to service urban environments (Cocchia 2014; Dameri 2013; Ratti and Townsend 2011).

These two ideologically opposed approaches have generated diverging opinions concerning their effectiveness. On the one hand, the model for measuring the maturity level of smart cities proposed by Lee and Hancock (2012) suggests the presence of a formalized and centralized top-down strategy aligned with the city's priorities is an important driver of smart city development and is preferable to a strategy based on a bottom-up approach. On the other hand, topdown smart cities are criticized by Shin $(2007 ; 2009 ; 2010)$, Townsend (2013) and Gooch et al. (2015) for their inability to effectively serve the people and meet their specific needs. This literature suggests that the smart cities resulting from a top-down approach are much more focused on fulfilling the market expectations and meeting the interests of major corporate suppliers working in the market of smart technologies, rather than society at large.

Additional support for bottom-up smart cities is provided by Bergvall-Kåreborn et al. (2009), Laydesdorff and Deakin (2011), Ratti and Townsend (2011) and Schuurman et al. (2012; 2016). This literature considers a radical shift from top-down innovation processes to open and bottom-up innovation as essential when dealing with smart city development, because "top-down visions ignore the enormous [and] innovative potential of grass-roots efforts" (Ratti and Townsend 2011: 45). This assumption is aligned with research undertaken by Deakin and Al Wear (2011), Alawadhi et al. (2012), Schaffers et al. (2012) and Deakin (2014a), who champion the importance of empowering citizens and providing them with the opportunity to become active actors of change in the making process of smart cities.

The last dichotomy relates to the intervention logic to be considered when implementing smart city development strategies. On the one hand, the European Commission has been promoting a mono-dimensional vision of smart cities, which are pictured as low-carbon and resource efficient urban environments that invest in ICT solutions for smart transport, smart buildings

\footnotetext{
${ }^{3}$ United Nations (1998), Food and Agriculture Organization (2013), World Economic Forum (2013), European Commission (2014b) and London School of Economics (Hutter and O'Mahony 2004) agree to define civil society as a broad category which encompasses non-governmental organizations (NGOs), community groups, charities, trusts, foundations, advocacy groups, faith-based organizations and national and international non-state associations.

4 The triple-helix collaborative model is based on university-industry-government relations (Etzkowitz and Leydesdorff 2000) and is embedded in the quadruple-helix model, which adds civil society organisations and citizens as fourth element of the collaborative ecosystem (Arnkil et al. 2010; Carayannis and Campbell 2014; Cavallini et al. 2016).
} 
and smart grids (European Commission 2009a; 2009b; 2011; 2012a; 2012b; 2016a; European Innovation Partnership on Smart Cities and Communities 2013). On the other hand, this energy-driven interpretation of smart city development is questioned by Manville et al. (2014), who suggest embracing an integrated and multi-dimensional approach is key to the implementation of successful strategies for smart city development, which need to cover as many application domains as possible.

This line of thinking is also found in the ranking system for measuring the performance of medium-sized European smart cities that Vienna University of Technology, University of Ljubljana and Delft University of Technology developed in 2007. According to this ranking system, successful smart city development strategies cover six application domains that are labelled using the following keywords: living, economy, people, environment, mobility and governance (Giffinger et al. 2007). A similar assessment of smart city development strategies has been proposed in the evaluation studies conducted by Lombardi et al. (2012) and Kourtit et al. (2014).

In addition, the multi-dimensional intervention logic is supported by IBM ${ }^{5}$ and Cisco Systems (2016a, 2016b), which promote their operating systems for smart cities: comprehensive ICT platforms that combine sets of digital solutions and applications to improve the management of urban systems, such as energy and utilities, parking, environment, safety and security, transportation, education and healthcare.

This extensive literature review uncovers the contradictions that smart city research has generated. These contradictions appear in the form of four dichotomies, which emerge from divergent hypotheses concerning what strategic principles drive smart city development. These hypotheses are listed in Table 1 and the scientific knowledge needed to empirically test their validity is acquired by conducting a deductive-based multiple case study analysis of four European leading examples of smart cities. The next section provides a comprehensive and thorough description of the research methodology used to conduct such an analysis ${ }^{6}$.

\begin{tabular}{l|l}
\hline DICHOTOMIES & STRATEGIC PRINCIPLES \\
\hline $\begin{array}{l}\text { Dichotomy 1: Technology-led or holis- } \\
\text { tic strategy }\end{array}$ & $\begin{array}{l}\text { Hypothesis 1.1: Technology-led strategy } \\
\text { Hypothesis 1.2: Holistic strategy }\end{array}$ \\
\hline $\begin{array}{l}\text { Dichotomy 2: Double or quadruple- } \\
\text { helix model of collaboration }\end{array}$ & $\begin{array}{l}\text { Hypothesis 2.1: Double-helix model of collaboration } \\
\text { Hypothesis 2.2: Quadruple-helix model of collaboration }\end{array}$ \\
\hline $\begin{array}{l}\text { Dichotomy 3: Top-down or bottom-up } \\
\text { approach }\end{array}$ & $\begin{array}{l}\text { Hypothesis 3.1: Top-down approach } \\
\text { Hypothesis 3.2: Bottom-up approach }\end{array}$ \\
\hline $\begin{array}{l}\text { Dichotomy 4: Mono-dimensional or } \\
\text { integrated intervention logic }\end{array}$ & $\begin{array}{l}\text { Hypothesis 4.1: Mono-dimensional intervention logic } \\
\text { Hypothesis 4.2: Integrated intervention logic }\end{array}$ \\
\hline
\end{tabular}

Table 1. The four dichotomies and divergent strategic principles emerging from the literature on smart cities

\footnotetext{
${ }^{5}$ See the official website of the IBM's Smarter Planet Initiative: http://www03.ibm.com/ibm/history/ibm100/us/en/icons/smarterplanet

6 This paper deploys the research methodology for conducting multiple case study analyses of smart city development strategies that Mora et al. (2018c) have assembled and piloted. Their research reports on the practical feasibility, effectiveness and logistics of such a methodology and is an additional source of information for those interested in better understanding the rationale behind it.
} 


\section{Research methodology}

This study reports on a multiple case study analysis conducted to start filling the knowledge gap generated by the dichotomous nature of smart city research and provide insights into what strategic principles European cities should consider when approaching the design and implementation of strategies for smart city development. To meet this aim, the divergent hypotheses emerging from the dichotomies are tested by analyzing a group of outstanding examples of European smart cities, i.e. cities in which smart city development strategies have been implemented and proved to be successful in serving urban development by adopting ICT-related solutions. The sampling process is conducted by means of a theoretical approach ${ }^{7}$ (Eisenhardt 1989; Patton 2002; Eisenhardt and Graebner 2007), which leads to the selection of Amsterdam, Barcelona, Helsinki and Vienna.

The success and international leadership of these European cities in the field of smart cities is demonstrated by reviewing the literature reporting on: (1) the prizes they have been awarded for their smart city development strategies; and (2) the smart city rankings and comparative analyses that are currently available, in which the four cities are shown to be as leading examples. The data resulting from this review is summarized in Appendix A.

The investigation is conducted by adopting a literal replication logic (Creswell 2009; George and Bennett 2005; Yin 2009). This ensures that the selected cases are subject to the same analytical process, which starts with the data collection phase. To establish what strategic principles have led these four cities towards becoming outstanding examples of smart city development, two databases are built and analyzed.

The first database groups and classify all the activities implemented by each city to enable smart city development. This classification is managed by adopting a system composed of four main categories (see Table 2) and allows the activities to be grouped according to the objectives and outcomes towards which efforts are directed. In the case of those activities which produce outcomes belonging to multiple categories, they are included in more than one group. The analysis of the percentage share related to each group makes it possible to determine whether the smart city development strategies under investigation are: (1) holistic or technology-led (Dichotomy 1); and (2) developed by means of a top-down or bottom-up approach (Dichotomy 3).

\begin{tabular}{c|l}
\hline CATEGORY & DESCRIPTION \\
\hline A. Community building & $\begin{array}{l}\text { Activities supporting the construction of an open and inclusive collaborative en- } \\
\text { vironment able to support the design and implementation of the smart city de- } \\
\text { velopment strategy. This is done by raising citizen engagement in the smart city } \\
\text { field, stimulating user-driven innovation and community-led urban development, } \\
\text { increasing public awareness and digital literacy, informing the city's stakehold- } \\
\text { ers and improving their level of understanding about smart city development } \\
\text { and the benefits it can generate }\end{array}$ \\
\hline B. Strategic framework & $\begin{array}{l}\text { Activities aiming to develop the city's strategic framework for guiding and regu- } \\
\text { lating smart city development. These activities produce: (1) action plans, pro- } \\
\text { grammes, guidelines, roadmaps, recommendations, governmental acts, policy } \\
\text { papers and documents; (2) measures proposing standards and technical re- } \\
\text { quirements, evaluation and assessment methods; and (3) workgroups that } \\
\text { manage the general course of the smart city development strategy's operations }\end{array}$ \\
\hline C. Services and applications & $\begin{array}{l}\text { Activities allowing new ICT services and applications to be integrated within the } \\
\text { city }\end{array}$ \\
\hline
\end{tabular}

${ }^{7}$ Case studies are not randomly selected, but chosen as laboratory experiments "for the likelihood that they will offer theoretical insight" (Eisenhardt and Graebner 2007: 27). 

and benefit from the available ICT services and applications. Examples of activities include the integration of urban operating systems and the construction or extension of high-speed broadband networks and public Wi-Fi networks

Table 2. Classification System 1

The activities belonging to the category "C. Services and applications" are then assigned to one or more application domains in order for the smart city development strategies' intervention logic to be analyzed (Dichotomy 4). This exercise is accomplished by deploying a second classification system which groups such activates according to the type of technological solutions that they have integrated within the city. This system is composed of 11 application domains, which are listed in Table 3 and compiled by merging the classification systems for smart technologies proposed to date (Giffinger et al. 2007; Manville et al. 2014; Neirotti et al. 2014; Reviglio et al. 2014; Cisco Systems 2016a; 2016b) ${ }^{8}$.

\begin{tabular}{|c|c|}
\hline APPLICATION DOMAINS & OBJECTIVES \\
\hline C.01. Energy networks & $\begin{array}{l}\text { To increase the efficiency and sustainability of either street lighting, or networks } \\
\text { for producing, storing and distributing energy }\end{array}$ \\
\hline C.02. Air & To ensure a better air quality in outdoor environments \\
\hline C.03. Water & To improve water resource management \\
\hline C.04. Waste & To improve waste management processes \\
\hline $\begin{array}{l}\text { C.05. Mobility and } \\
\text { transport }\end{array}$ & $\begin{array}{l}\text { To provide city users with more sustainable and accessible transport systems and } \\
\text { address mobility issues }\end{array}$ \\
\hline $\begin{array}{l}\text { C.06. Buildings and dis- } \\
\text { tricts }\end{array}$ & $\begin{array}{l}\text { To improve the efficiency, accessibility and management systems of buildings and } \\
\text { districts }\end{array}$ \\
\hline $\begin{array}{l}\text { C.07. Health and Social } \\
\text { Inclusion }\end{array}$ & $\begin{array}{l}\text { To improve the quality, accessibility and organization of health services and sup- } \\
\text { port social inclusion }\end{array}$ \\
\hline C.08. Cultural heritage & $\begin{array}{l}\text { To ensure a better protection of both tangible and intangible cultural heritage and } \\
\text { enhance their cultural value }\end{array}$ \\
\hline C.09. Education & $\begin{array}{l}\text { To increase the quality of teaching-learning processes delivered by education sys- } \\
\text { tems }\end{array}$ \\
\hline $\begin{array}{l}\text { C.10. Public safety and } \\
\text { security }\end{array}$ & To ensure safety and security in urban spaces and face safety challenges \\
\hline C.11. E-government & $\begin{array}{l}\text { To increase the convenience and accessibility of public services and information } \\
\text { to city users }\end{array}$ \\
\hline C.12. Other & $\begin{array}{l}\text { ICT services and applications aiming at producing benefits different than those } \\
\text { related to the previous application domains }\end{array}$ \\
\hline
\end{tabular}

Table 3. Classification System 2

The activities grouped in the first database are mapped and analyzed by cross-referencing the qualitative data extracted from multiple sources. Digital records produced by the city governments are considered as primary sources. These include the followings data items: agendas; minutes of meetings; press releases; news and newsletters; conference presentations; conference speeches obtained from either presentations' notes or videos of the events; reports; brochures; governmental acts; policy papers and documents; and webpages. Additional data is acquired from records produced by organizations that are either collaborating with the city governments in implementing the city's smart city development strategy, or not directly involved but interested in providing data describing the programmes of activities that have

\footnotetext{
${ }^{8}$ See also IBM (http://www-03.ibm.com/ibm/history/ibm100/us/en/icons/smarterplanet).
} 
been undertaken. These sources are considered as secondary and include, for example, reports produced by consultancy firms, research project deliverables, news and articles found in online magazines and scientific literature. This approach makes it possible to conduct the multiple case study analysis by considering the data provided by both internal and external observers. Overall, 2011 digital records in either written, audio, photographic or video form are processed in this study ${ }^{9}$. These records are found between April and October 2016 by conducting a series of online searches in which Google's web search engine and multiple search strings are deployed. No restrictions for languages are set during the searches.

Coding is used to organize the large volume of unstructured qualitative data collected from the digital records and facilitate both the identification of the activities and their progressive analysis. The coding process is conducted by deploying the software Atlas.ti (Version 1.0.51) and following the procedure suggested by Eisenhardt (1989), Gibbs (2007), Robson (1993) and Strauss and Corbin (1990). After being uploaded onto Atlas.ti, the digital records are reviewed repeatedly to identify the activities that every city selected as case study has implemented to develop its own smart city development strategy. During the coding process, every activity is assigned a code, so as the sections of text or other data items describing the following attributes ${ }^{10}$ : (1) objectives of the activity; (2) generated or expected outcomes; and (3) organizations involved in its development. The coding process results in four detailed reports in which the activities of each city were listed and the data necessary to study them was presented in a structured and well-organized form.

The reports are generated by using Atlas.ti's output function Codebook and used to: (1) populate the first database; and (2) structure the second one, in which the organizations identified during the coding process are individually listed and classified according to their type (see Table 4). The information necessary to classify the organizations is obtained from their official websites, because the data provided by the digital records was insufficient to complete this task. In addition, the data related to each activity is checked to establish if citizens have been involved in the implementation process. These actions are instrumental in assembling the inter-organizational collaborative networks of the four smart city development strategies and establish whether their structure is based on a double or quadruple-helix model (Dichotomy 2).

\begin{tabular}{|c|c|}
\hline CATEGORY & DESCRIPTION \\
\hline Research & Universities and other research and educational institutions \\
\hline Industry & $\begin{array}{l}\text { Businesses which are involved in consultancy activities and/or in the distribution of goods and } \\
\text { services }\end{array}$ \\
\hline Government & $\begin{array}{l}\text { Local, regional and national governmental authorities, along with their majority-owned sub- } \\
\text { sidiaries and external agencies }\end{array}$ \\
\hline Civil Society & Civil society organizations \\
\hline Other & $\begin{array}{l}\text { Organizations that do not belong to the previous categories or where the information neces- } \\
\text { sary to complete the classification is not available }\end{array}$ \\
\hline
\end{tabular}

Table 4. Classification System 3

\section{Multiple case study analysis}

With the coding process, 263 activities are mapped and their breakdown by city and category is shown in Figure 1 and Appendix B. The analysis of these activities makes it possible to test the validity of the hypotheses that each dichotomy proposes in a European context and explain how the case studies have approached smart city development.

\footnotetext{
9 The number of digital records by city is: Amsterdam, 329; Barcelona, 1,032; Helsinki, 165; Vienna, 485

10 The data items different from text include pictures, maps, technical drawings and sections of audio and video files.
} 


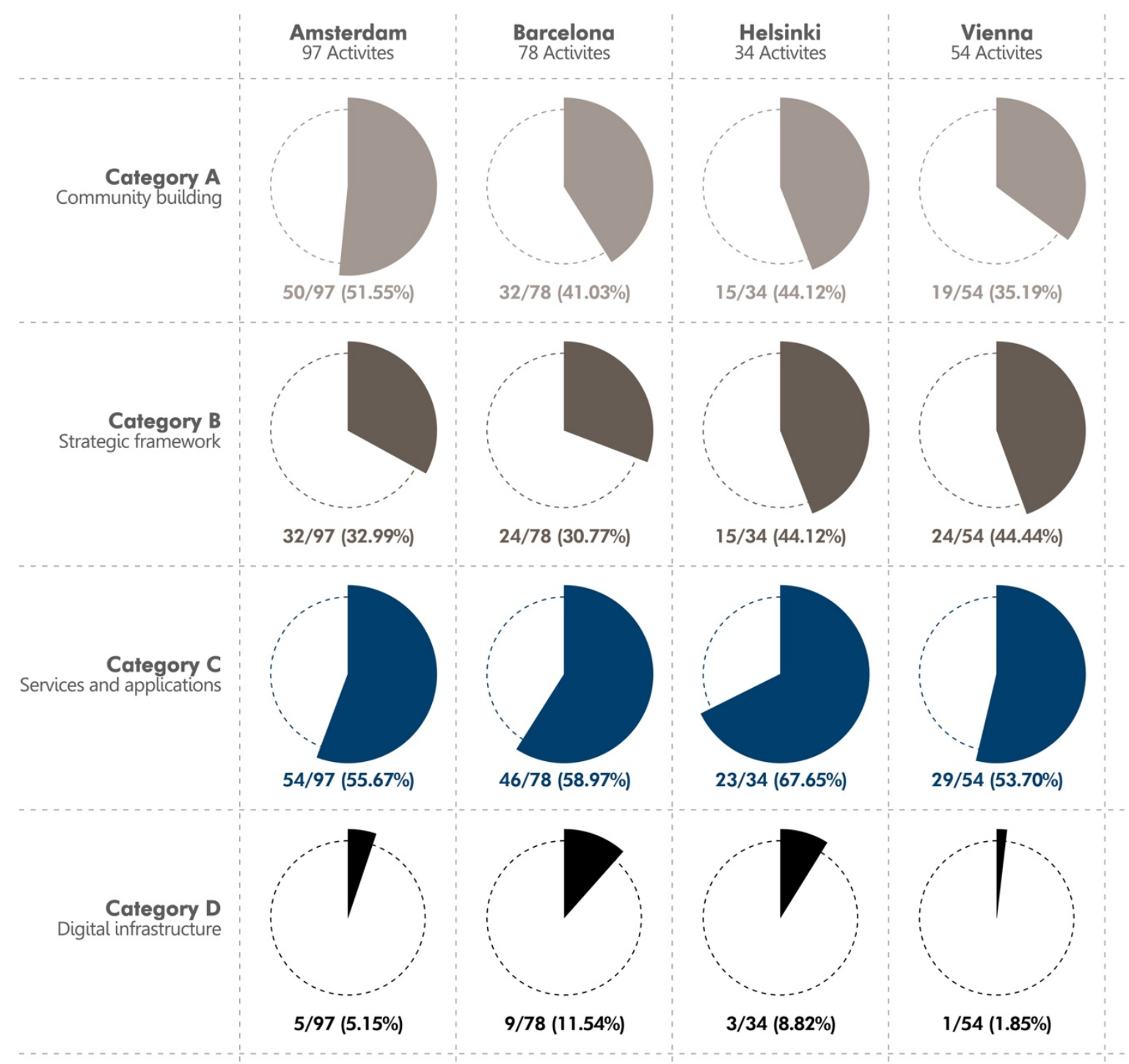

Figure 1. Number and percentage of activities by city and category

\subsection{Dichotomy 1: Technology-led or holistic strategy}

To design and implement their smart city development strategies, Amsterdam, Barcelona, Helsinki and Vienna have adopted a very similar approach and selected a course of action that gives equal weight and attention to: the deployment of technological advancements for either resolving or mitigating urban issues; and the development of both a strategic framework and an open and inclusive collaborative environment for enabling the progressive deployment of such technological advancements. The four cities have therefore embraced a holistic vision of smart cities and consider them not as technology-only focused systems resulting from the massive combination of sets of interconnected ICT devices and infrastructures, but as sociotechnical systems in which technological development is aligned with human, social, cultural, economic and environmental factors.

This assumption can be demonstrated by looking at the data in Figure 2, in which the number and percentage of activities by city and group of categories are compared and appear to be balanced in each strategy. The first group includes the activities belonging to at least one of the first two categories, i.e. "A. Community building" and "B. Strategic framework". These activities are entirely or partially focused on building the city's capacity to support smart city 
development by creating: (1) a comprehensive strategic framework able to provide long-term sustainability and drive the efforts of individuals and organizations towards the same direction; and (2) an open, inclusive and engaging collaborative environment strengthening the abilities of such individuals and organizations to act in concert and actively participate in the co-creation of ICT-driven initiatives that bring innovation and improvements into the city.

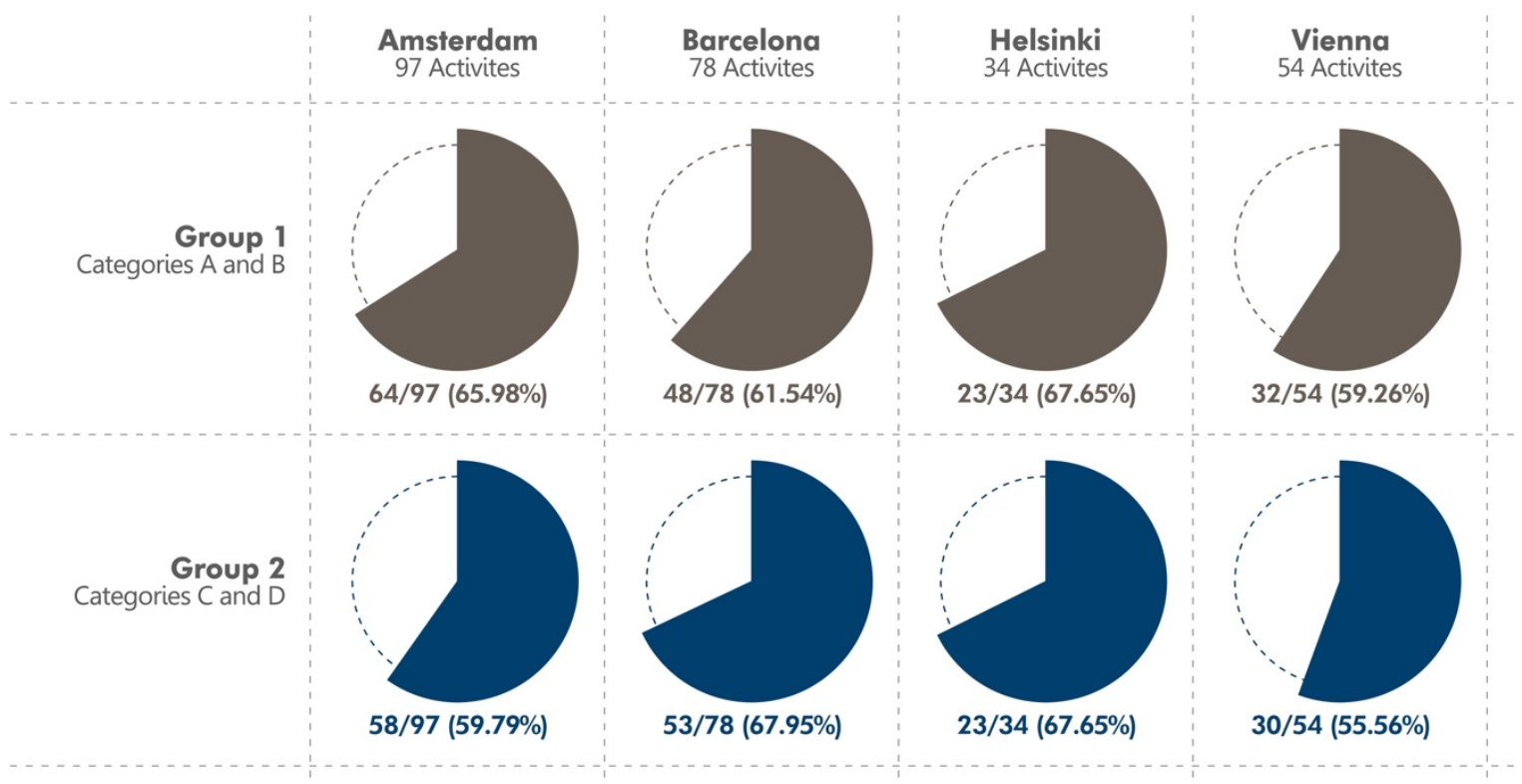

Figure 2. Number and percentage of activities by group of categories

For example, with the projects, CitySDK, Commons4EU, Smart Together and Open Cities, the four cities have developed and deployed new user-driven innovation methodologies to: empower local communities and increase their degree of participation in the smart city domain; and foster co-creation processes of digital services of public interest (Bria et al. 2015). To further stimulate collaboration, Amsterdam has also launched StartUpBootcamp, an accelerator programme that connects start-ups working in the field of smart cities with mentors, partners and investors who help to improve the quality of their products and services. This activity aims to boost the city's entrepreneurial culture and accelerate the development of new cityscale digital innovation initiatives.

Additional examples of capacity-building activities are:

- CLUE, TRANSFORM and Urban Learning, three European projects that allow Vienna, Barcelona and Amsterdam to improve the city government's capability to deliver policy and programs for fighting climate change with ICT solutions (Brandt et al. 2014; CLUE Project Partners 2014; Hartmann et al. 2015; Hemis et al. 2017);

- Helsinki Loves Developers, in which regular meetings are organized to open a dialogue between Helsinki's app developers on the benefits of open data and enhance their collaboration (Forum Virium Helsinki 2014);

- Cibernarium, the City of Barcelona's training programme for increasing professionals and citizens' knowledge, skills, attitudes and behaviours in the effective use of digital devices.

The second group of activities is instead composed of projects and initiatives in which the deployment of ICT services, applications and infrastructures in the built environment is among the objectives that are listed. Examples of technological solutions include: mobile apps and open source platforms for planning customized urban routes in Barcelona and Helsinki; QR codes allowing visitors to get free guided tours along some of Helsinki's sights by using their 
smartphones; new public Wi-Fi hotspots in Barcelona and Amsterdam; a platform for stimulating the use of renewable energy and changing energy consumption behaviors of Amsterdam's city users; and decision-supporting tools for managing the infrastructures of urban energy and mobility systems in Vienna (City of Barcelona 2012c; Rafiq et al. 2013; Sanseverino et al. 2014; 2017; Wiener Modellregion and Climate and Energy Fund 2014; Bednar et al. 2016; Marguerite et al. 2016) ${ }^{11}$.

\subsection{Dichotomy 2: Double or quadruple-helix model of collaboration}

The collaborative model adopted in each of the smart city development strategies is graphically visualized by using the open-source software Gephi (Version 0.9.1) and its FruchtermanReingold layout algorithm (Fruchterman and Reingold 1991). This data visualization exercise results in four social-network graphs (see Appendix $\mathrm{C}$ ), which describe the interaction among the organizations involved in the development of the activities mapped during the coding process, along with their degree of participation. In the networks, organizations are represented as nodes with a diameter that is directly proportional to the number of activities that they have contributed to implement, while the edges connect the organizations which have worked together. The stronger the degree of collaboration between two organizations, the higher the weight of the edge that connects them and its thickness in the graph.

The data describing the networks' structures is illustrated in Figure 3 and shows that the design and implementation process of the four smart city development strategies has required collaborative environments with hundreds of heterogeneous organizations. With 407 and 255 nodes, Barcelona and Vienna have respectively the largest and the smallest communities. Amsterdam and Helsinki's networks are instead composed of about 350 nodes each. Despite some differences in size, what these networks have in common is the distribution of organizations by type. With a participation level between $46 \%$ and $56 \%$, businesses are always the most active organizations and are followed by institutions for education and research, which represent approximately $20 \%$ of each collaborative network. The remaining organizations are divided between Government and Civil Society. However, while the former varies between $22 \%$ and $13 \%$, the latter always remains below $10 \%$, especially in the cases of Vienna and Helsinki, where the figures are $4.3 \%$ and $6.3 \%$.

The data shows that public and private sector collaboration is the core engine behind the four smart city development strategies under investigation and the programme of activities that they have implemented. These programmes mainly result from a triple-helix model of collaboration based on the interaction between Research, Industry and Government. Civil society organizations are the less represented organization type, along with citizens. This assumption can be confirmed by looking at the data in Figure 4, which reveals the number of activates that citizens have been actively involved in the implementation of. The data shows that citizens' participation cover approximately between $24 \%$ and $59 \%$ of the overall activates.

These statistics suggest civil society organizations and citizens are not fully integrated in the collaborative ecosystems. However, they also demonstrate that the four cities have made an effort to connect innovation and civil society by stimulating citizens' active involvement in the development of smart city projects and initiatives. Despite being found only in a limited number of initiatives, such an effort provides evidence of an attempt to move towards a quadruplehelix collaborative model and the open and user-centric innovation approach it stands for (Arnkil et al. 2010; Cavallini et al. 2016). This aim is clearly expressed in the strategic frameworks that the four cities have developed for guiding and regulating smart city development (City of

\footnotetext{
${ }^{11}$ Additional information about the projects discussed in this section can be found in the following official websites: Smart Together (http://smarter-together.eu); StartUpBootcamp (https://www.startupbootcamp.org); Helsinki Loves Developers (https://dev.hel.fi); Cibernarium (https://cibernarium.barcelonactiva.cat); Energy Atlas (https://amsterdamsmartcity.com/projects/energy-atlas).
} 
Amsterdam 2011; 2014a; 2014b; 2015; City of Barcelona and Doxa Consulting 2012; City of Barcelona 2012a; 2012b; 2014; City of Vienna 2014; City of Helsinki 2015).

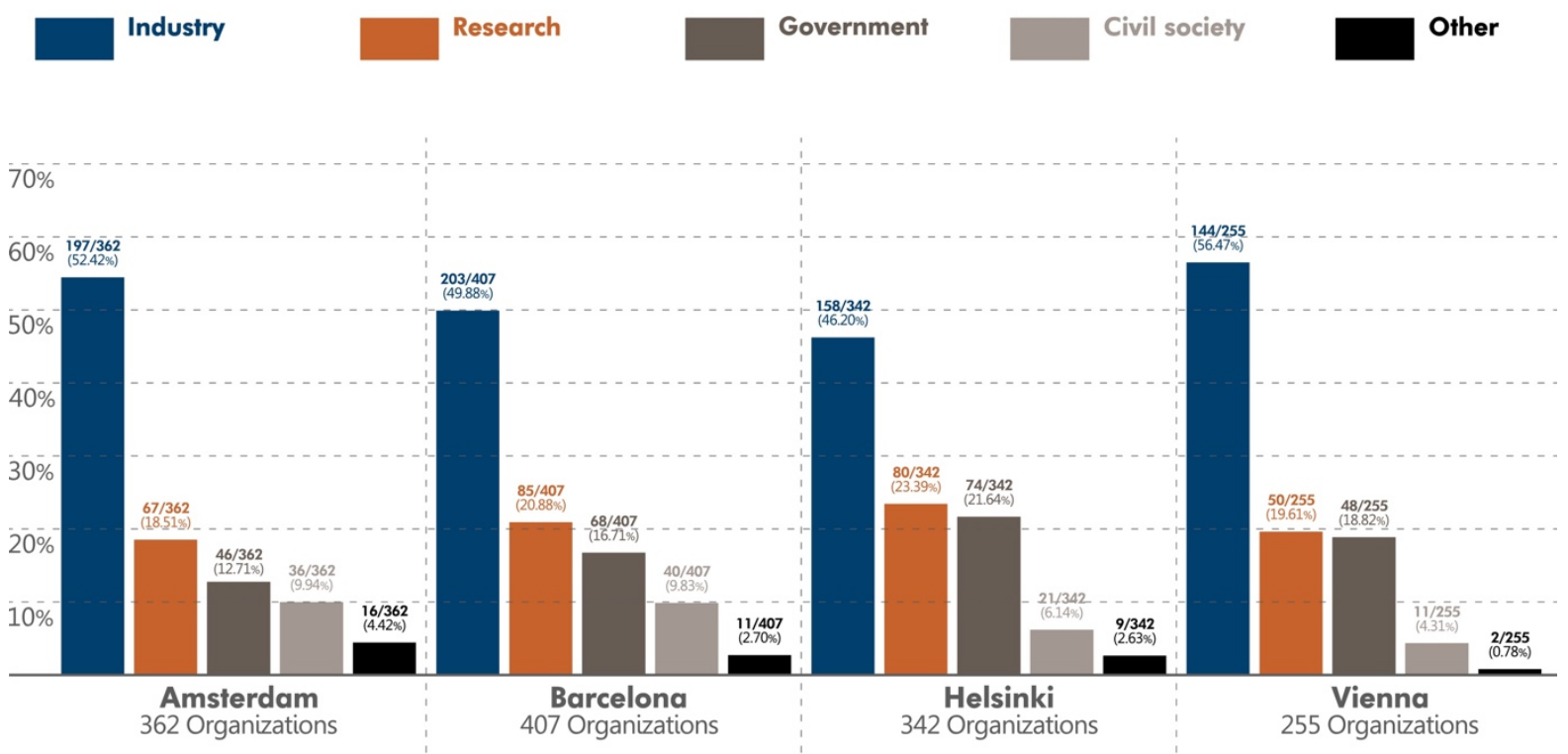

Figure 3. Distribution of organizations by type

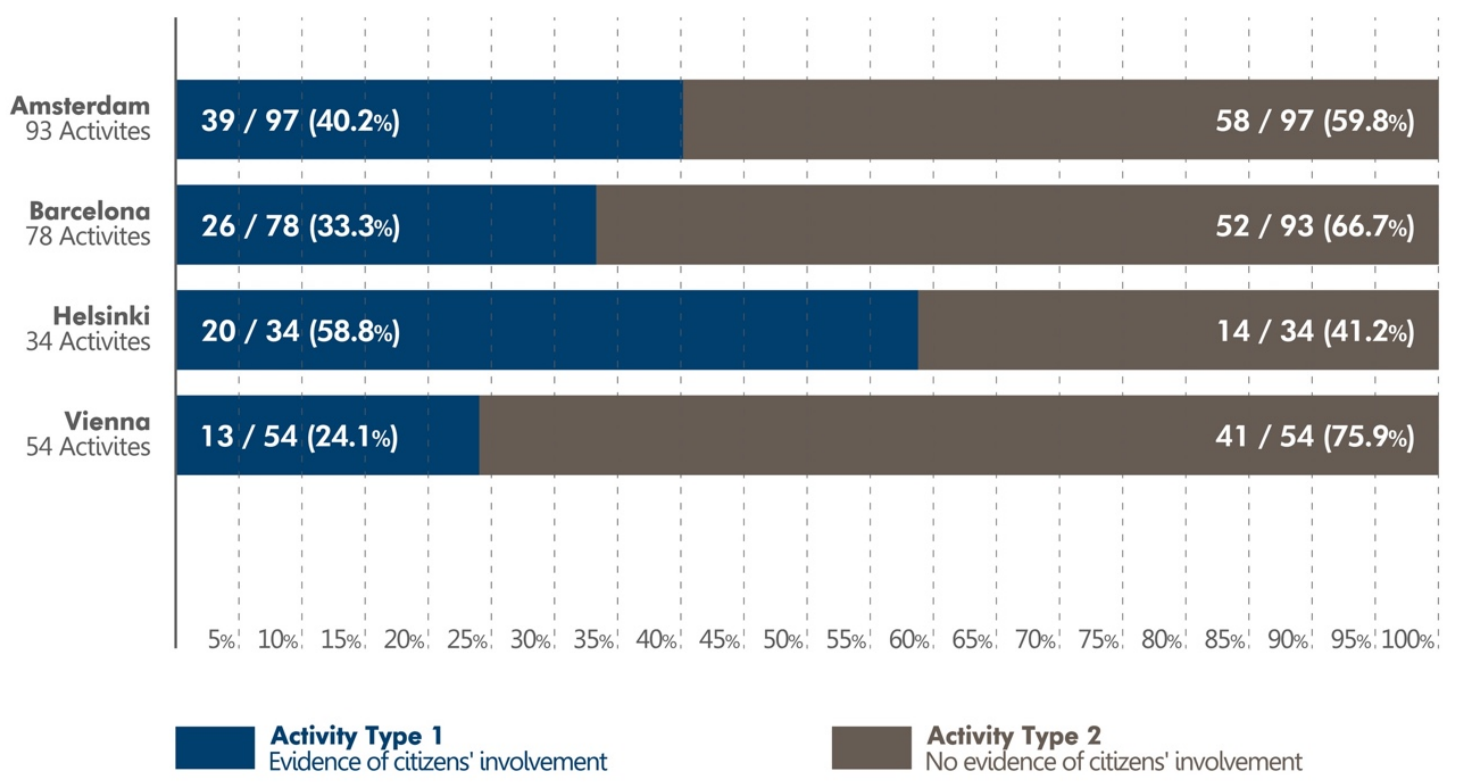

Figure 4. Citizens' involvement in smart city activities

The analysis of the activities show that citizens have been asked to participate as either: (1) users who test ICT solutions and provide feedback; (2) developers who are given support for producing new digital services of public interest; or (3) residents expressing their ideas and needs during workshops and meetings with other stakeholders. For example, citizens have been invited to collaborate in producing Vienna's smart city strategic framework by attending a series of stakeholders' forums. These forums have been conceived as discussion events for exchanging ideas and opinions and ensuring greater transparency, participation and collaboration in the smart city domain. This approach is also adopted in the case of Amsterdam, 
where citizens have been involved in meetings and workshops organized to debate on their needs and possible ICT-driven projects and initiatives able to meet them (City of Vienna et al. 2011; 2013; City of Vienna 2012; 2013a; 2013b; 2016; Mora and Bolici 2017).

In addition, the Living Lab methodology has been used to increase citizens' participation in the testing phases of the ICT solutions and infrastructures to be deployed in the built environment, so as to further develop and network public services. During the delivery of the Street Smart project, for example, Helsinki has piloted a mobile application with a group of citizens who have provided feedback through an online questionnaire ${ }^{12}$. The same approach has been used in Barcelona during the piloting phase of the decision support system for monitoring buildings' energy consumption that has resulted from the project BESOS. Additional examples of projects in which the four cities have adopted user-centric innovation methodologies include: APOLLON; Sustainable Neighborhood Geuzeveld; West Orange; Climate Street; Energy Management Haarlem; Smart Challenge; Smart Citizen Kit; Smart Cities Demo Aspern (SCDA); and Smarter Together (Amsterdam Innovation Motor and Liander 2011; Brinkman 2011; Aspern Smart City Research 2015; Bria et al. 2015; Henriquez 2015; Panos et al. 2016; Muhlmann 2017).

Civil society's active involvement in the smart city domain has also been encouraged by means of hackathons and competitions, in which citizens have been invited to apply their knowledge and skills for developing new digital services able to face urban challenges. These events have been organized to nurture citizens' entrepreneurial creativity and digital talent. Some example captured during the mapping exercise include the followings: BCN Apps Jam Recicla; Smart Cities Hackathon; Smart City App Hack; Apps4bcn Competition; Apps for Amsterdam; Apps4Finland; Open Helsinki - Hack at Home; and Open Finland Challenge (Afman et al. 2011; Forum Virium Helsinki 2014; 2015; Mora and Bolici 2016; 2017).

\subsection{Dichotomy 3: Top-down or bottom-up approach}

Amsterdam, Barcelona, Helsinki and Vienna's approach to smart city development maintains a balance between top-down and bottom-up approaches. The four city governments are one of the most active organizations in each smart city ecosystem and have contributed to implement between $44 \%$ and $91 \%$ of the total activities (see Appendix B). This data suggests local governments have played a crucial role and provide evidence of their commitment to supporting smart city development. In addition, by looking at the objectives and outcomes related to the activities they have undertaken, it is possible to note that the city governments have not made use of their position to centralize the implementation process of the smart city development strategies but acted instead as leaders who aim to: (1) encourage the establishment of an open, inclusive and cohesive collaborative ecosystem by bringing large groups of individuals and organizations together; (2) provide these large communities with a strategic framework able to guide their efforts towards the same direction and make full use of both their collective intelligence and common interest in smart city development; (3) enable this collaborative ecosystem to grow; and 4) stimulate bottom-up development processes.

To achieve these aims, the four municipal administrations have adopted a very similar approach and implemented activates that made it possible to:

- shape smart city strategic frameworks composed of policy documents that formally state their commitment to support smart city development and: provide long-term vision; establish the objectives to be achieved in order for local communities to prosper; suggest the main application domains to focus attention on; and introduce the governance systems which are set up to support and speed up the transition process towards becoming smart (City of Amsterdam 2011; 2014a; 2014b; 2015; City of

\footnotetext{
12 Additional information on the Street Smart project can be found at https://helsinkistreetlab.fi
} 
Barcelona and Doxa Consulting 2012; City of Barcelona 2012a; 2012b; 2014; City of Vienna 2014; City of Helsinki 2015);

- increase the cities' know-how on urban technologies and their capability to manage smart city development by supporting the making and deployment of new: planning and operational tools; user-driven innovation methodologies; recommendations; guidelines; standards and technical requirements; and evaluation and assessment methods (Brandt et al. 2014; Hartmann et al. 2015; Hemis et al. 2017; CLUE Project Partners 2014; City of Barcelona 2014; Bria et al. 2015; Amsterdam Innovation Motor and Liander 2011); ${ }^{13}$

- organize forums, conferences, workshops, learning programmes and meetings dealing with smart city development in order to: collect ideas, comments and feedback about the cities' ICT requirements; generate interest; inform the community; engage new stakeholders and make the collaborative ecosystem larger; raise public awareness of the potential benefits that ICTs can produce in urban environments; increase digital literacy; and stimulate collaboration (City of Vienna 2012; 2013a; 2013b; Forum Virium Helsinki 2014; Mora and Bolici 2016; 2017; Amsterdam Innovation Motor and Liander 2011; City of Barcelona and Doxa Consulting 2012) ${ }^{14}$;

- build platforms for open-data provision and organize hackathons and competitions in order to support IT-skilled individuals and organizations in producing new applications and digital services by using public data (Afman et al. 2011; Forum Virium Helsinki 2014; 2015; Mora and Bolici 2016; 2017; Waag Society 2011) ${ }^{15}$.

In addition, the local governments have also assembled dedicated working groups which have been tasked with managing smart city development and the multidisciplinary, heterogeneous and technologically innovative environment necessary to make it grow. These groups mainly cover the areas of coordination, stakeholder management, communication, promotion, monitoring and assessment of smart city projects. In addition, they have been requested to accelerate the progressive integration of new digital services and technological infrastructures within the city in the short and medium term by: extending participation and strengthening the capacity of citizens and organizations for collaboration in the field of smart cities; forming consortia of cross-sectoral partners for innovative projects; offering access to regional and international networks; and providing information on financial instruments.

The best practice analysis shows that the responsibility for managing these functions and establishing a strong collaborative culture has been assigned to:

- the Amsterdam Economic Board, which is coordinating Amsterdam Smart City, a collaborative platform resulting from a public-private programme launched in $2009 ;{ }^{16}$

- Forum Virium Helsinki (2015), a non-profit organization owned by the City of Helsinki;

- TINA Vienna, which is part of Wien Holding GmbH (2012), a holding company of the City of Vienna that carries out community tasks (City of Vienna 2014);

- the Barcelona City Council's Municipal Institute of Information Technology (City of Barcelona 2012b; 2016).

\footnotetext{
13 See also the following projects: CityOpt (http://www.cityopt.eu); TRANSFORM (http://urbantransform.eu); PUMAS (www.pumasproject.eu); TRANSFORM+ (http://www.transform-plus.at); EU-GUGLE (http://eu-gugle.eu); and INNOSPIRIT (http://www.innospirit.org).

${ }^{14}$ See also Digital City Wien (https://digitalcity.wien).

${ }^{15}$ Examples of open-data platforms include the followings: Amsterdam City Data (https://data.amsterdam.nl); Open Data BCN (http://opendata-ajuntament.barcelona.cat); Helsinki Region Infoshare (http://www.hri.fi); and Open Government Vienna (https://www.data.gv.at).

16 The Amsterdam Smart City programme was launched in 2009 by Amsterdam Innovation Motor and Liander (2011), in close cooperation with the City of Amsterdam. Starting from 2013, the Amsterdam Innovation Motor has become part of the Amsterdam Economic Board (The Technopolicy Network 2014; Amsterdam Innovation Motor 2009). It is important to note that, in the analysis of the Amsterdam's smart city collaborative network, the two entities have been merged.
} 


\subsection{Dichotomy 4: Mono-dimensional or integrated intervention logic}

The analysis of the activities belonging to the category "C. Services and Applications" shows that the four cities have adopted an integrated intervention logic that covers a mix of application domains (see Figure 5). However, when comparing the cities' level of interest in each application domain, there is significant variation.

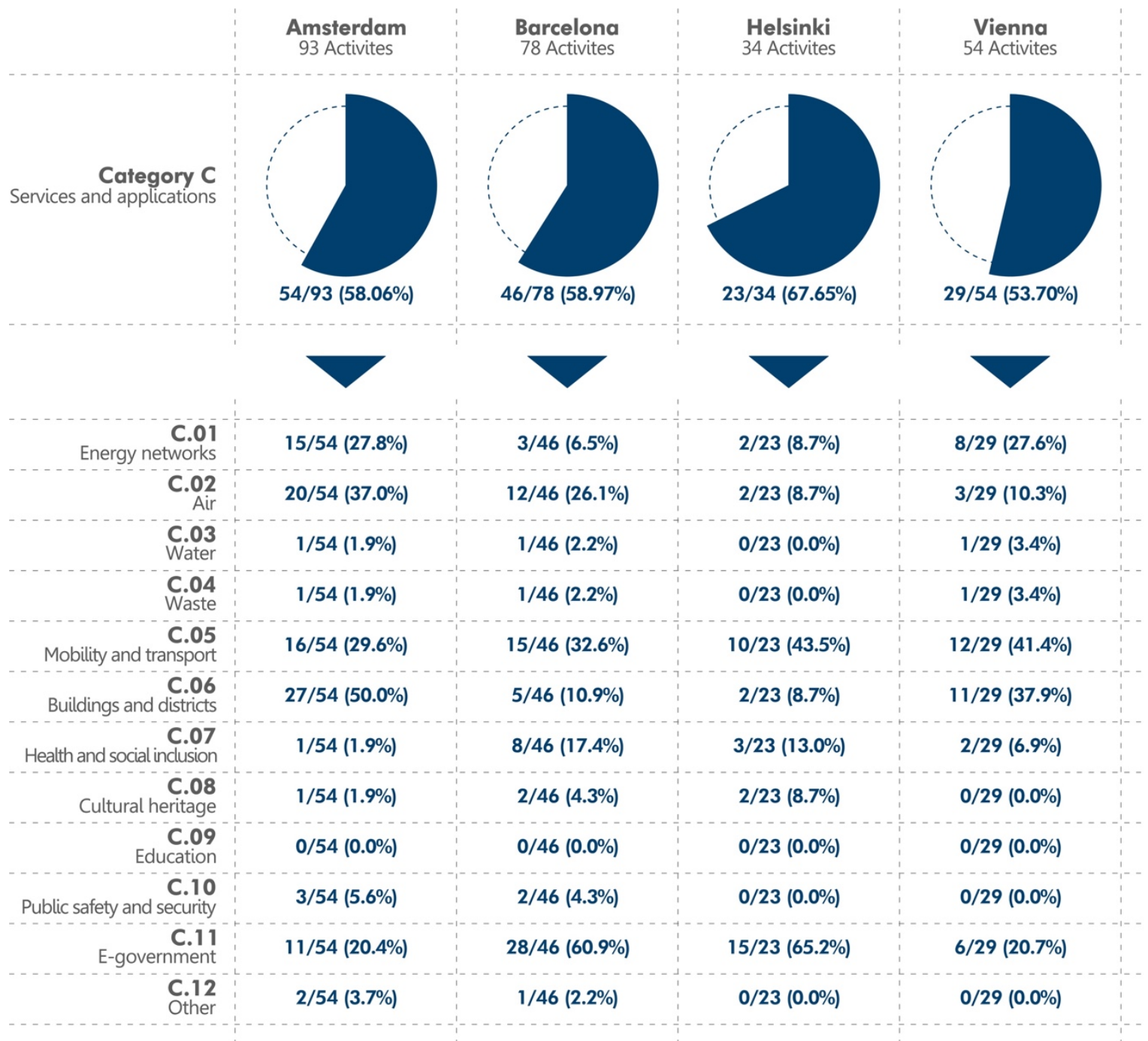

Figure 5. Number and percentage of activities by application domain

Vienna and Amsterdam's interest in smart city development is mainly oriented towards smart transport, smart building and smart grid solutions for low-carbon and energy efficient urban environments. Most of the ICT-related services and applications supporting their smart city development strategies are deployed to fight climate change and boost energy efficiency in mobility and transport (C.05), buildings and city districts (C.06), and power infrastructures (C.01). Their approach to smart city development is therefore aligned with the European Commission's interpretation of smart cities. However, the data reveals that both cities have extended such a mono-dimensional vision by focusing attention on additional policy domains and urban challenges. For example, technological solutions are deployed to: improve the management of natural resources other than energy; increase the quality of public transport services by providing citizens with real-time information; stimulate collaboration and communication between residents, businesses, governmental authorities and welfare organizations by means of digital platforms; provide citizens with digital solutions for working remotely rather 
than commuting from home to offices; and improve people's health and wellbeing in the context of an ageing population.

The interest in transport is also shared by Barcelona and Helsinki, where respectively $33 \%$ and $43 \%$ of the technological solutions are linked to this application domain. However, most of their initiatives relates to e-government (C.11), where ICT solutions are intended to increase the convenience and accessibility of public data and services. Also, Barcelona and Helsinki are both particularly active in the field of health and social inclusion (C.07), in which ICTs are mainly deployed to assist elderly people in their everyday lives ${ }^{17}$.

\section{Strategic principles for smart city development: lessons from Europe}

In May 2016, the European Union's Ministers responsible for Urban Matters agreed to establish an Urban Agenda for the European Member States, which promotes a new model of urban development and contribute to the implementation of both the United Nations' 2030 Agenda for Sustainable Development and the New Urban Agenda issued by the Habitat III Secretariat. These three international policy documents all stress the important role that sustainable urban development plays in increasing economic prosperity, social and territorial cohesion and wellbeing at a global level. They also recognize smart city development as an integral part of sustainable urban development processes, with smart technologies that provide cities with the opportunity to become safer and more inclusive, resilient and sustainable (European Commission 2016b; United Nations 2015; 2017).

The United Nations' policy paper on urban services and technology further emphasizes this recommendation by highlighting the potential that smart city development has to support transformative changes in society by helping cities to address the increasingly complex challenges that they are currently facing. However, this policy paper also recognizes the presence of a knowledge gap with regard to how cities can enable such a development and, in response, calls for a better theoretical and practical understanding that current research on smart cities is still unable to offer (United Nations 2016).

The ambiguity generated by the four dichotomies that Mora et al. $(2017 ; 2018 a ; 2018 b)$ and Komninos and Mora (2018) have captured in their studies provides a fundamental challenge that must be addressed before it is possible to clearly articulate what needs to be done in order for urban environments to be successful in enabling smart city development. The deductive multiple-case study analysis that this paper reports on does help meet this challenge. It focuses attention on Europe, where the validity of the hypotheses that each dichotomy proposes is tested by examining the way in which four best practices have gone about the design and implementation of their smart city development strategies. The results of this analysis are summarized in Figure 6, which shows the choices that have allowed Amsterdam, Barcelona, Helsinki and Vienna to address the dichotomous nature of smart city research and successfully enable ICT-related development and innovation in urban environments.

The lessons learned and new insights captured by this best practice analysis make it possible to establish a set of strategic principles instructing European cities on the path to follow in designing and implementing smart city development strategies able to produce meaningful results and be successful in meeting urban challenges by means of ICT solutions. These strategic principles are proposed to support decision-making processes in the field of smart city

\footnotetext{
17 See the following projects: CO2 Neutrale; SternE; SeniorTab; Citybike Wien; E-Taxis; SMILE; AnachB; Wien.at live-App; Open Government Data; Wien Gestalten (https://smartcity.wien.gv.at); Smart Citizen Kit; Smart Work@ljburg; Health-Lab; Change by Us in Amsterdam (https://amsterdamsmartcity.com); Smart Urban Spaces (http://www.smarturbanspaces.org); Projecte Radars; Servei de teleassistència municipal; Vincles BCN; and EsclaTIC (http://ajuntament.barcelona.cat/digital).
} 
development and speed up the effective deployment of smart technologies in European urban environments.

\section{DICHOTOMIES}
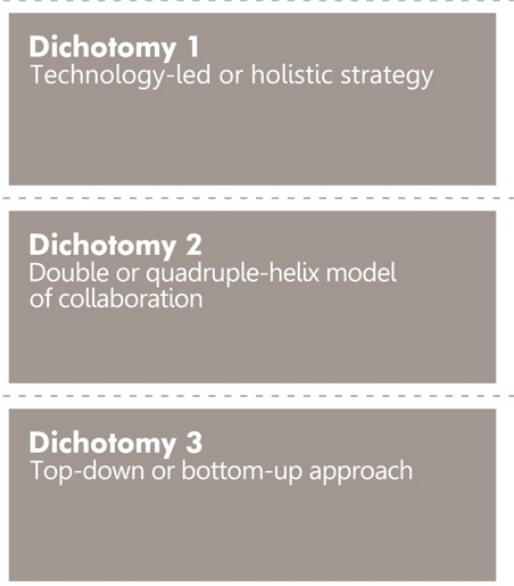

Dichołomy 4

Mono-dimensional or integrated

intervention logic

\section{STRATEGIC PRINCIPLES}
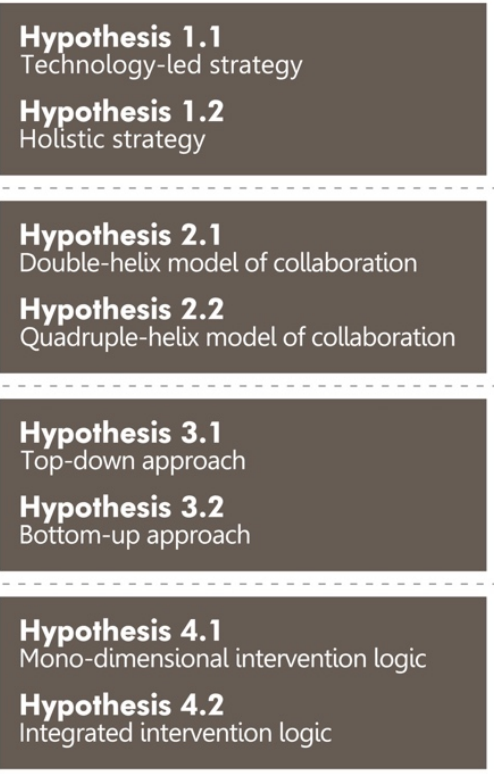

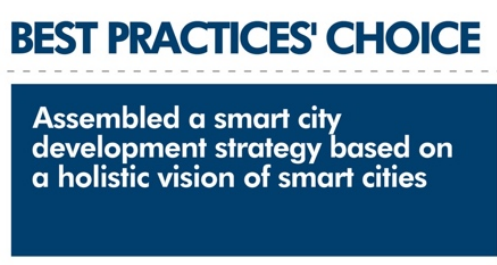

Exploited the triple-helix model of collaboration and made efforts to move towards a quadruple-helix collaborative ecosystem

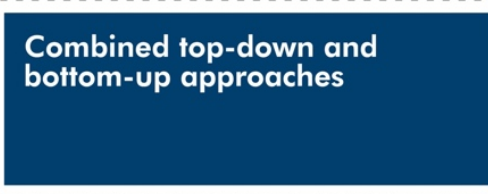

Adopted an integrated intervention logic

Figure 6. Dichotomies and divergent strategic principles: the best practices' choices

\section{Strategic principle 1: Look beyond technology}

Enabling smart city development is a challenge going far beyond technology. These four leading European smart cities have proven to be complex socio-technical systems in which smart city development results from the integration of new ICT services, applications and infrastructures for either resolving or mitigating urban challenges. The development process of this technological layer is progressive and recalls the idiomatic expression of Urban Acupuncture, which refers to Jaime Lerner (2014)'s approach to modern urban development, i.e. to continuously implement large numbers of small-scale projects that progressively improve the urban context instead of relying upon massive urban renewal projects. This approach suggests dealing with urban development in an era of constrained budgets and limited resources requires a more dynamic, flexible and community-based line of action. The European best practices have applied this Urban Acupuncture in the field of smart city development, which has been enabled by the continuous implementation of short and medium-term ICT-related interventions that have gradually transformed the cities into smart environments.

However, to let this progressive digital transformation take place, the case studies show that significant efforts must be oriented towards building the capacity of the city to integrate and deploy such technological solutions. This requires cities to: (1) align technological development with the contents of a holistic and comprehensive strategic framework able to provide long-term sustainability and drive individuals and organizations in the same direction; and (2) build an open, inclusive and engaging collaborative environment that strengthen the capacity of these individuals and organizations to work together and actively participate in the co-creation of ICT-driven initiatives that bring innovation and improvements into the city.

\section{Strategic principle 2: Move towards a quadruple-helix collaborative model}

Collaboration is key to successful implementation of smart city development strategies and 
supporting the growth of an open, inclusive and engaging collaborative environment is pivotal to this. In developing this collaborative environment, it is important to: (1) rely on public and private sector collaboration; (2) institute the industry-government-research relationships of the triple-helix collaborative model; and (2) make significant efforts to strengthen the participatory qualities of civil society by progressively moving towards a quadruple-helix model of stakeholder engagement and the open and user-centric innovation approach it promotes (Arnkil et al. 2010; Carayannis and Campbell 2014; Cavallini et al. 2016).

Strong engagement mechanisms and user-driven innovation methodologies are necessary to bring together large communities composed of heterogeneous organizations representing the Triple Helix and to increase citizens' participation in co-creation processes of digital services of public interest. Working with citizens sets a complex challenge because it requires moving away from "an era of linear, top-down and expert-driven development, production and services [and start] practicing with different forms and levels of co-production" (Arnkil et al. 2010: III). However, this makes it possible to gain high-value place-based knowledge that can be exploited in the integration and deployment process of ICT-related urban innovations (Mathie and Cunningham 2003; Curwell et al. 2005; Deakin and Allwinkle 2007; Torres et al. 2006; Veeckman and van der Graaf 2014; Bria et al. 2015). As suggested by the United Nations' guidelines for sustainable and socially inclusive urban infrastructure, citizen participation can: "improve the quality of decision making and facilitate the execution of actions; [...] provide a better way of dealing with cross-cutting issues; [...] and help ensure that actions taken and services provided reflect the needs of people more adequately" (Santucci et al. 2011: 52).

Engagement plans and stakeholder analysis techniques can be useful tools for mapping key actors and understanding both their interests and the potential contribution they may offer (Brandon et al. 2017; Future Cities Catapult and Arup 2017; Moghadam et al. 2017). Examples of stakeholder engagement for managing smart city development strategies are described in research by lelite et al. (2015) and Mayangsari and Novani (2015), which respectively report on the experiences of Riga and Bandung.

\section{Strategic principle 3: Combine top-down (government-led) and bottom-up (community- driven)}

As suggested by Breuer et al. (2014), Lee et al. (2014), Exner (2015), Angelidou (2017) and Mora and Bolici (2016; 2017), smart city development "requires a two-pronged approach: topdown (government-led) to build foundations and bottom-up (community-driven)" (Estevez et al. 2016: VII) "A purely top-down view on the smart city carries a danger of authoritarianism with it, while a bottom-up-only approach leans towards chaos and lack of long-term vision" (Breuer et al. (2014: 162), therefore, they need to be combined.

Governments have a central role in the design and implementation of strategies for smart city development, but their activity needs to be oriented towards creating the favorable conditions for individuals and organizations to pool their knowledge, skills and interests and collaborate in delivering smart city projects and initiatives. To achieve this aim, city governments are required to put smart city development among the priorities of their political agenda and assemble a strategic framework and a smart city accelerator, which are both instrumental in: (1) building the open, inclusive and cohesive collaborative environment needed to activate smart city development and the bottom-up development process required to achieve this; (2) facilitating the creation of partnerships for jointly implementing ICT-related initiatives; and (3) coordinating the efforts of this collaborative environment towards achieving a common set of goals which reflect the vision and priorities of the city.

In addition, the local government's action is needed to improve the city's capacity to enable smart city development. This can be done through activities which aim to: generate feedback on the cities' ICT requirements and new ideas for ICT-related activities; generate interest and 
inform the community; stimulate collaboration; engage new stakeholders and help the collaborative ecosystem to grow; raise public awareness of the potential benefits that ICTs can produce in urban environments; and increase the level of digital literacy within the city.

Open data initiatives like app contests, hackathons and codefests are an interesting example of activities for building capacity by raising awareness, increasing participation and stimulating community-driven development in the smart city domain, especially from citizens. By hosting these events, city governments bring together groups of IT-skilled individuals which are invited to conceive new digital applications to address urban concerns by using public data (Johnson and Robinson 2014; Irani 2015; Komssi et al. 2015; Lodato and DiSalvo 2016; Carr and Lassiter 2017; Concilio et al. 2017).

Forums, conferences, workshops and training courses are additional activities that cities are using to increase their capacity to sustain smart city development. Barcelona has been organising the Smart City Expo World Congress since 2011. This event has become a leading global platform for experts working in the field of smart city development, which are brought together to share knowledge and debate ${ }^{18}$. Barcelona has also launched a Smart Education programme for primary and secondary schools in order to bring the concepts of innovation and smartness to kids through practical activities and workshops. Turin has instead offered intensive training courses on the management of smart city development strategies to executives and directors working for the City Council (Pisu 2015).

\section{Strategic principle 4: Build a strategic framework}

The policy documents composing the city's strategic framework for smart city development need to clearly establish: a long-term vision highlighting ambitions and motivations driving the smart city transformation process; the expected outcomes and targets to achieve by deploying ICT solutions; the main application domains to focus attention on; and the working group responsible for managing and accelerating the implementation of the strategy.

Along with Amsterdam, Barcelona, Helsinki and Vienna, further examples of cities that have designed comprehensive strategic frameworks for driving smart city development include New York, Turin, Heraklion and Birmingham. "New York has created a stand-alone strategy in the early 2010s but has now integrated its digital plans within the overall city vision in order to help think about technology more holistically" (Future Cities Catapult and Arup 2017: 23). Turin's strategic framework was launched in 2013 and resulted from an elaboration process based on strategic urban planning principles. More than 350 key experts representing governmental authorities, businesses, universities, research centres and civil society organizations have been involved (Carcillo and Macii 2013; Deambrogio 2013). The same participatory approach has been applied by Heraklion and Birmingham, which have both designed strategic plans for smart city development in order to help the stakeholders to work together instead of operating independently of one another (URBACT Secretariat 2017; Digital Birmingham 2012; 2014).

Despite being at an early stage of investigation (Komninos 2014; Angelidou 2014; Ben Letaifa 2015; Mora and Bolici 2016; 2017; Marsal-Llacuna and Segal 2016; 2017), strategic planning tools and techniques appear to be particularly useful when adopted to deal with the design process of such strategic frameworks. For example, scenario building, collaborative vision building, stakeholder analyses and focus groups have been deployed by the city of Vienna to produce a long-term vision, along with a roadmap and an action plan for guiding the city's urban transformation dynamics in the smart city domain (Hofstetter and Vogl 2011). In addition, potential for smart city development can be tested by means of SWOT analyses (ÁlvarezGarcía et al. 2017).

${ }^{18}$ Additional information on the Smart City Expo World Congress and Barcelona's Smart Education programme can be found at http://www.smartcityexpo.com and http://cordis.europa.eu/news/rcn/136756 it.html 


\section{Strategic principle 5: Boost the digital transformation by establishing a smart city ac- celerator}

In addition to the strategic framework, local governments are also required to assemble a smart city accelerator: a working group which is dedicated to accelerating the progressive transformation of the city in a smart environment, by strengthening the capacity of individuals and organizations to collaborate in delivering innovative ICT-related initiatives. Based on the lessons learnt with the best practice analysis, the main activities that these working groups need to carry out are the followings: boost the production of new ideas for ICT-related interventions; engage new potential partners and facilitate the creation of new consortia; provide information on financial instruments and funding mechanisms that can be used to finance projects and initiatives; offer access to regional and international networks; monitor the ICTrelated interventions and assure they are aligned with the strategic framework's contents; and generate interest by promoting the smart city development strategy in order to facilitate the creation of new partnerships and the acquisition of new resources.

Considering the experiences of Amsterdam, Barcelona, Helsinki and Vienna, the smart city accelerators can be: (1) part of either the City Council, or other existing organizations that carry out community tasks; or (2) set up by establishing new public-private organizations which are autonomous and provided with independent legal identities. Examples of the latter type can also be found in Genoa and Turin, where the smart city development strategies are respectively managed by the Genoa Smart City Association and Torino Smart City Foundation. Both organizations have resulted from the collaboration between the City Council and a group of public and private organizations, which belong to the city's metropolitan area and represent industry, government and research (Deambrogio 2013; Sanseverino et al. 2014; Grossi and Pianezzi 2017). Unfortunately, no research has been conducted yet to investigate how these different types of smart city accelerators work, especially in different urban contexts, and what benefits and disadvantages each of them offers.

\section{Strategic principle 6: Adopt an integrated intervention logic}

The energy-driven interpretation of smart city development sets boundaries that cities need to overcome. Smart city development pathways need to be shaped according to each city's socio-economic and cultural background and the selection of the application domains depends on local context factors (Neirotti et al. 2014). These factors include the urban challenges that the city has to tackle, which are not always energy or environmental-related. Therefore, it is important to adopt an integrated intervention logic that: (1) cuts across the multitude of application domains that smart city development represents; and (2) extends the benefits that ICT solutions can offer to any policy sectors of the city. This requires cities to have a clear understanding of both the urban issues limiting their sustainable growth and the technological advancements to be deployed in order to either mitigate or fully resolve such issues.

Once again, strategic planning tools and techniques can help obtain this knowledge related to urban issue and technological fixes. For example, open consultations through digital platforms and applications can be deployed to actively engage citizens and other relevant stakeholders in the identification of urban issues and local needs (Pentikousis et al. 2011). Issues and possible technological solutions may then be matched by adopting strategic decision processes, such as Technology Roadmapping. Roadmapping processes for smart city development have been analysed by Lee et al. (2013) and adopted by Birmingham (Fullard 2016).

\section{Conclusions}

This paper formulates a set of strategic principles that European cities should take into consideration in order to successfully design and implement smart city development strategies. 
These principles suggest enabling smart city development in Europe requires to:

- Look beyond technology;

- Move towards a quadruple-helix collaborative model;

- Combine top-down (government-led) and bottom-up (community-driven);

- Build a smart city strategic framework;

- Boost the digital transformation by establishing a smart city accelerator;

- Adopt an integrated intervention logic.

The strategic principles that this paper proposes are sourced from a multiple case study analysis which focuses attention on four European best practices: Amsterdam, Barcelona, Helsinki and Vienna. Further research is therefore needed to generalize the lessons which have been learned with this analysis to regional contexts beyond Europe, and continue to build the knowhow necessary to fully overcome the knowledge gap that the dichotomous nature of smart city research has generated. This requires smart city researchers to: (1) identify examples of both leading and unsuccessful smart city development strategies belonging to non-European countries; and (2) process additional case study analyses to test the validity of the strategic principles that this paper puts forward.

Extending the generalization of this paper's findings by conducting additional research into the design and implementation of smart city development strategies is also instrumental in enabling peer-learning and knowledge transfer processes able to support evidence-based decision-making. The scientific literature demonstrates that a large number of cities across Europe and beyond are working on strategies for enabling smart city development. Gathering, codifying and sharing the practical knowledge produced by these real-life experiences, in the form of good practices and recommendations, is key to succeed in dealing with the ambiguity surrounding smart city development strategies and their design and implementation process. This knowledge can be exploited to create the conditions for continuous learning and innovation, which both serve to accelerate the adoption of strategies that progress smart city development. For example, such a knowledge can be used for: (1) building transnational knowledgesharing platforms that connect cities together and let them learn from each other, as in the case of the digital market place of the European Innovation Partnership on Smart Cities and Communities $^{19}$; (2) developing and delivering learning events and educational strategies; and (3) supporting the production and deployment of decision-making support tools for underpinning the design and implementation of smart city development strategies.

Future research should also be conducted into the application of strategic planning tools and techniques in the field of smart city development strategies. The paper's findings suggest this area is promising and a number of cities are already experimenting in this innovative domain. Examples of highly-valuable research activates aiming at increasing the collective understanding in this knowledge domain include the followings: mapping what strategic planning tools and techniques are being used and providing detailed examples able to explain why and how to apply them; and identifying additional instruments which have not been deployed yet, but that hold promise for the future.

\section{References}

ABB (2013). ABB Power and Automation: Solid Foundations for Smart Cities. White paper. ABB. http://new.abb.com/docs/default-source/smart-grids-library/abb_smart_grids_white_paper_2013.pdf?sfvrsn=2. Accessed 05.04.2014.

Achaerandio, R., Gallotti, G., Curto, J., Bigliani, R., and Maldonado, F. (2011). Smart Cities Analysis in Spain. White paper. IDC. http://www.idc.com/getdoc.jsp?containerld=EIRS56T. Accessed 06.08.2014.

Afman, S., Boonstra, R., Demeyer, T., Gallyas, K., Jansen-Dings, I., Kresin, F., Reitenbach, M., Schot, M., and Slaghuis, L. (2011). Apps for Amsterdam: A City Opening Up. Waag Society. https://waag.org/sites/waag/files/public/Publicaties/A4A_OpenCities_pub.pdf. Accessed 05.09.2016.

19 See http://eu-smartcities.eu 
Aina, Y. A. (2017). Achieving Smart Sustainable Cities with GeolCT Support: The Saudi Evolving Smart Cities. Cities: The International Journal of Urban Policy and Planning, 71, 49-58.

Alawadhi, S., Aldama-Nalda, A., Chourabi, H., Gil-Garcia, R. J., Leung, S., Mellouli, S., Nam, T., Pardo, T. A., Scholl, H. J., and Walker, S. (2012). Building Understanding of Smart City Initiatives. In H. J. Scholl, M. Janssen, M. A. Wimmer, C. E. Moe, and L. S. Flak (Eds.), Electronic Government: 11th IFIP WG 8.5 International Conference, EGOV 2012, Kristiansand, Norway, September 3-6, 2012. Proceedings (pp. 40-53). Berlin: Springer.

Albino, V., Berardi, U., and Dangelico, R. M. (2015). Smart Cities: Definitions, Dimensions, Performance, and Initiatives. Journal of Urban Technology, 22(1), 3-21.

Álvarez-García, J., de la Cruz del Río-Rama, M., Vázquez-Huerta, G., and Rueda-Armengot, C. (2017). Smart City and Tourism: An Analysis of Development of Caceres (Spain) As a Smart City. In M. Peris-Ortiz, D. R. Bennett, and D. Pérez-Bustamante Yábar (Eds.), Sustainable Smart Cities: Creating Spaces for Technological, Social and Business Development (pp. 199-218). Cham: Springer.

Alvin Yau, K., Lau, S., Chua, H. N., Ling, M. H., Iranmanesh, V., and Charis Kwan, S. C. (2016). Greater Kuala Lumpur As a Smart City: A Case Study on Technology Opportunities. In 2016 8th International Conference on Knowledge and Smart Technology (KST), Chiangmai, 3-6 February 2016 (pp. 96-101). Piscataway, NJ: Institute of Electrical and Electronics Engineers (IEEE).

Amato, V., Bloomer, L., Holmes, A., and Kondepudi, S. (2012a). Government Competitiveness Drives Smart+connected Communities Initiative. White paper. Cisco Systems. http://www.smartconnectedcommunities.org/docs/DOC-2174. Accessed 04.01.2013.

Amato, V., Kondepudi, S., and Holmes, A. (2012b). Transforming Communities with Smart+connected Services. White paper. Cisco Systems. http://www.smartconnectedcommunities.org/docs/DOC-2129. Accessed 04.01.2013.

Amsterdam Innovation Motor (2009). Amsterdam Capital of Science: ICT in Business. Amsterdam Innovation Motor. http://www.amsterdameconomicboard.com/download.php?itemID=294. Accessed 08.08.2016.

Amsterdam Innovation Motor, and Liander (2011). Smart Stories. Amsterdam Smart City. https://issuu.com/amsterdamsmartcity/docs/smart_stories. Accessed 05.08.2016.

Amsterdam Smart City (2011). Smart Stories. Amsterdam Smart City. https://issuu.com/amsterdamsmartcity/docs/smart stories. Accessed 05.08.2016.

Anderson, J., Fisher, D., and Witters, L. (2012). Getting Smart About Smart Cities: Understanding the Market Opportunity in the Cities of Tomorrow. Alcatel-Lucent. http://www2.alcatel-lucent.com/knowledge-center/ad$\mathrm{min} / \mathrm{mci}$-files-1a2c3f/ma/Smart_Cities_Market_opportunity_MarketAnalysis.pdf. Accessed 01.01.2013.

Angelidou, M. (2014). Smart City Policies: A Spatial Approach. Cities: The International Journal of Urban Policy and Planning, 41(Supplement 1), S3-S11.

Angelidou, M. (2017). The Role of Smart City Characteristics in the Plans of Fifteen Cities. Journal of Urban Technology, 24(4), 3-28.

Angelidou, M., and Psaltoglou, A. (2017). An Empirical Investigation of Social Innovation Initiatives for Sustainable Urban Development. Sustainable Cities and Society, 33, 113-125.

Arnkil, R., Järvensivu, A., Koski, P., and Piirainen, T. (2010). Exploring Quadruple Helix: Outlining User-oriented Innovation Models. Working paper. University of Tampere. https://tampub.uta.fi/bitstream/handle/10024/65758/978-951-44-8209-0.pdf?sequence=1. Accessed 10.07.2016.

Aspern Smart City Research (2015). Aspern Smart City Research: Energieforschung Gestaltet Energiezukunft. Aspern Smart City Research. http://www.ascr.at/wp-content/uploads/2015/09/ASCR_Folder_dt.pdf. Accessed 03.05.2017.

Baccarne, B., Mechant, P., and Schuurman, D. (2014a). Empowered Cities? An Analysis of the Structure and Generated Value of the Smart City Ghent. In R. P. Dameri, and C. Rosenthal-Sabroux (Eds.), Smart City: How to Create Public and Economic Value with High Technology in Urban Space (pp. 157-182). Cham: Springer.

Baccarne, B., Schuurman, D., Mechant, P., and De Marez, L. (2014b). The Role of Urban Living Labs in a Smart City. In XXV ISPIM Innovation Conference: Innovation for Sustainable Economy and Society, Dublin, 8-11 June 2014 Manchester: International Society for Professional Innovation Management.

Bakici, T., Almirall, E., and Wareham, J. (2013). A Smart City Initiative: The Case of Barcelona. Journal of the Knowledge Economy, 4(2), 135-148.

Bansal, S., Pandey, V., and Sen, J. (2017). Redefining and Exploring the Smart City Concept in Indian Perspective: Case Study of Varanasi. In F. Seta, J. Sen, A. Biswas, and A. Khare (Eds.), From Poverty, Inequality to Smart City: Proceedings of the National Conference on Sustainable Built Environment 2015 (pp. 93-107). Singapore: Springer.

Bednar, T., Bothe, D., Forster, J., Fritz, S., Haufe, N., Kaufmann, T., Eder-Neuhauser, P., Pfaffenbichler, P., Rab, N., Schleicher, J., Weinwurm, G., Winkler, C., and Ziegler, M. (2016). URBEN-DK: Results Report. Report. TU Wien. https://urbem.tuwien.ac.at/fileadmin/t/urbem/files/URBEM_Ergebnisbericht_Einzelseiten_EN.pdf. Accessed 05.08.2017.

Ben Letaifa, S. (2015). How to Strategize Smart Cities: Revealing the SMART Model. Journal of Business Research, 68(7), 1414-1419.

Bergvall-Kåreborn, B., Ihlström Eriksson, C., Ståhlbröst, A., and Svensson, J. (2009). A Milieu for Innovation Defining Living Labs. In Proceedings of the 2nd ISPIM Innovation Symposium, New York City, NY, 6-9 December 2009 Manchester: International Society for Professional Innovation Management (ISPIM).

Bolici, R., and Mora, L. (2015). Urban Regeneration in the Digital Era: How to Develop Smart City Strategies in Large European Cities. TECHNE: Journal of Technology for Architecture and Environment, 5(2), 110-119.

Brandon, P. S., Lombardi, P., and Shen, G. Q. (Eds.) (2017). Future Challenges in Evaluating and Managing 
Sustainable Development in the Built Environment. Oxford: John Wiley \& Sons Ltd.

Brandt, N., Cambell, F., Deakin, M., Johansson, S., Malmström, M., Mulder, K., Pesch, U., Shahrokni, H., Tatarchenko, O., and Årman, L. (2014). European Cities Moving Towards Climate Neutrality. http://www.clueproject.eu/getfile.ashx?cid=69201\&cc $=5 \&$ refid=6. Accessed 08.07.2017.

Brech, B., Rajan, R., Fletcher, J., Harrison, C., Hayes, M., Hogan, J., Hopkins, L., Isom, P. K., Meegan, J., Penny, C., Snowdon, J. L., and Wood, D. A. (2011). Smarter Cities Series: Understanding the IBM Approach to Efficient Buildings. IBM Corporation. http://www.redbooks.ibm.com/redpapers/pdfs/redp4735.pdf. Accessed 14.09.2012.

Breuer, J., Walravens, N., and Ballon, P. (2014). Beyond Defining the Smart City: Meeting Top-down and Bottomup Approaches in the Middle. TeMA: Journal of Land Use, Mobility and Environment, 7, 153-164.

Bria, F., Gascó, M., Halpin, H., Baeck, P., Almirall, E., and Kresin, F. (2015). Growing a Digital Social Innovation Ecosystem for Europe: DSI Final Report. European Union. https://www.nesta.org.uk/sites/default/files/dsireport.pdf. Accessed 03.01.2017.

Brinkman, J. (2011). Supporting Sustainability Through Smart Infrastructures: The Case of Amsterdam. Network Industries Quarterly, 13(3), 22-25.

Buscher, V., and Doody, L. (2013). Global Innovators: International Case Studies on Smart Cities. BIS Research Paper $\mathrm{n}^{\circ} 135$. United Kingdom Government - Department for Business, Innovation and Skills. https://www.gov.uk/government/uploads/system/uploads/attachment_data/file/249397/bis-13-1216-global-innovators-international-smart-cities.pdf. Accessed 08.09.2016.

Caragliu, A., Del Bo, C., and Nijkamp, P. (2011). Smart Cities in Europe. Journal of Urban Technology, 18(2), 6582.

Carayannis, E. G., and Campbell, D. (2014). Developed Democracies Versus Emerging Autocracies: Arts, Democracy, and Innovation in Quadruple Helix Innovation Systems. Journal of Innovation and Entrepreneurship, 3(12), 1-23.

Carcillo, F., and Macii, E. (2013). Torino Smart City: Strategic Planning and Practical Deployment. City of Turin and Polytechnic University of Turin. https://events.hkstp.org/events/Past_AIS/CMS/files/03_Franco_and_Enrico_web_.pdf. Accessed 10.10.2016.

Cardullo, P., and Kitchin, R. (2017). Being a Citizen in the Smart City: Up and Down the Scaffold of Smart Citizen Participation. Working paper. Maynooth University. https://osf.io/preprints/socarxiv/v24jn. Accessed 12.09.2017.

Carr, S. J., and Lassiter, A. (2017). Big Data, Small Apps: Premises and Products of the Civic Hackathon. In P. Thakuriah, N. Tilahun, and M. Zellner (Eds.), Seeing Cities Through Big Data (pp. 543-559). Cham: Springer.

Carvalho, L. (2015). Smart Cities from Scratch? A Socio-technical Perspective. Cambridge Journal of Regions, Economy and Society, 8(1), 43-60.

Cavallini, S., Soldi, R., Friedl, J., and Volpe, M. (2016). Using the Quadruple Helix Approach to Accelerate the Transfer of Research and Innovation Results to Regional Growth. European Union - Committee of the Regions. http://cor.europa.eu/en/documentation/studies/Documents/quadruple-helix.pdf. Accessed 08.11.2016.

Chen-Ritzo, C., Harrison, C., Paraszczak, J., and Parr, F. (2009). Instrumenting the Planet. IBM Journal of Research and Development, 53(3), 338-353.

Christopoulou, E., Ringas, D., and Garofalakis, J. (2014). The Vision of the Sociable Smart City. In N. Streitz, and P. Markopoulos (Eds.), Distributed, Ambient, and Pervasive Interactions: Second International Conference, DAPI 2014, Held as Part of HCl International 2014, Heraklion, Crete, Greece, June 22-27, 2014. Proceedings (pp. 545-554). Berlin: Springer.

Cisco Systems (2012). Smart Cities Exposé: 10 Cities in Transition. Cisco Systems. http://www.pageturnpro.com/Cisco/41742-Smart-Cities-Expose-10-Cities-in-Transition/index.html\#44. Accessed 05.01.2013.

Cisco Systems (2016a). Cisco Smart+Connected Digital Platform: At-a-glance. Cisco Systems. http://www.cisco.com/c/dam/en_us/solutions/industries/docs/at-a-glance-c45-736521.pdf. Accessed 20.06.2017.

Cisco Systems (2016b). Cisco Smart+Connected Digital Platform: Data Sheet. Cisco Systems. http://www.cisco.com/c/dam/en_us/solutions/industries/docs/datasheet-c78-737127.pdf. Accessed 20.06.2017.

City of Amsterdam (2011). Structuurvisie Amsterdam 2040: Economisch Sterk En Duurzaam. City of Amsterdam. http://www.amsterdam.nl/publish/pages/434856/structuurvisie_def_maart2011_web.pdf. Accessed 15.07.2016.

City of Amsterdam (2014a). De Circulaire Metropool Amsterdam 2014-2018. City of Amsterdam. http://www.amsterdam.nl/publish/pages/599296/de_circulaire_metropool_amsterdam_2014_2018_printversie_2mb_versie_-_20140618.pdf. Accessed 15.07.2016.

City of Amsterdam (2014b). European Strategy for Amsterdam: Progress in Sustainable Urban Development in 2013. City of Amsterdam. http://www.amsterdam.nl/publish/pages/600373/european_strategy_web.pdf. Accessed 15.07.2016.

City of Amsterdam (2015). Sustainable Amsterdam: Agenda for Renewable Energy, Clear Air, a Circular Economy and a Climate-resilient City. City of Amsterdam. https://www.amsterdam.nl/publish/pages/675721/sustainable amsterdam_27-3-2015.pdf. Accessed 02.08.2016.

City of Barcelona (2012a). Marc Estratègic I Full De Ruta 2012-2015. City of Barcelona. http://www.bcn.cat/pdf/bases pam/document base.pdf. Accessed 25.08.2016.

City of Barcelona (2012b). Mesura De Govern MES: L'estratègia TIC De L'Ajuntament De Barcelona AI Servei De 
La Ciutat I Dels Ciutadans. City of Barcelona. http://governobert.bcn.cat/sites/default/files/MG_Cultura_TIC_300312.pdf. Accessed 25.08.2016.

City of Barcelona (2012c). User Manual: Barcelona WiFi. City of Barcelona. http://ajuntament.barcelona.cat/barcelonawifi/docs/en/manual.pdf. Accessed 12.10.2016.

City of Barcelona (2014). Mesura De Govern. Pla Director De Les TIC: Desplegament D'Infraestructures "Smart" a L'Espai Públic (PDTIC). City of Barcelona. http://governobert.bcn.cat/sites/default/files/Pla\%20Director\%20de\%20les\%20TIC.pdf. Accessed 25.08.2016.

City of Barcelona (2016). IMI - Municipal Institute of Information Technology. City of Barcelona. http://ajuntament.barcelona.cat/imi/en/documents. Accessed 05.12.2016.

City of Barcelona, and Doxa Consulting (2012). Barcelona Smart City: The Vision, Focus and Projects of the City of Barcelona in the Context of Smart Cities. City of Barcelona. http://ibarcelona.bcn.cat/sites/default/files/vision_focus_and_projects_of_bcn_in_smart_cities_context.pdf. Accessed 25.08.2016.

City of Birmingham (2012). Birmingham's Smart City Commission Vision. City of Birmingham. http://s3-eu-west1.amazonaws.com/digitalbirmingham/resources/Birminghams-Smart-City-Commission-Vision-FINAL-VERSION.pdf. Accessed 07.08.2016.

City of Birmingham (2014). The Roadmap to a Smarter Birmingham. City of Birmingham. https://birminghamsmartcity.files.wordpress.com/2014/03/birmingham_smart_city_roadmap_03_03_20141.pdf. Accessed 07.08.2016.

City of Helsinki (2015). Helsingin Kaupungin Tietotekniikkaohjelma 2015-2017. City of Helsinki. http://www.hel.fi/static/helsinki/julkaisut/tietotekniikkaohjelma.pdf. Accessed 08.09.2016.

City of Vienna (2012). Smart City Wien Stakeholder Forum: Wo Stehen Wir. City of Vienna. https://www.wien.gv.at/stadtentwicklung/studien/pdf/b008327.pdf. Accessed 01.09.2016.

City of Vienna (2013a). Smart City Wien Stakeholder Forum: Auf Dem Weg Zur Smart City Wien Rahmenstrategie. City of Vienna. https://www.wien.gv.at/stadtentwicklung/studien/pdf/b008381.pdf. Accessed 01.09.2016.

City of Vienna (2013b). Smart City Wien Stakeholder Forum: Innovation Durch Smarte Projekte. City of Vienna. https://www.wien.gv.at/stadtentwicklung/studien/pdf/b008328.pdf. Accessed 01.09.2016.

City of Vienna (2014). Smart City Wien: Framework Strategy. City of Vienna. https://smartcity.wien.gv.at/site/files/2014/09/SmartCityWien_FrameworkStrategy_english_doublepage.pdf. Accessed 30.08.2016.

City of Vienna (2016). Stakeholder-Prozesse - Smart City Wien. City of Vienna. https://www.wien.gv.at/stadtentwicklung/projekte/smartcity/stakeholder.html. Accessed 01.09.2016.

City of Vienna, 3420 Aspern Development AG, Siemens AG Österreich, Österreichisches Forschungs- und Prüfzentrum Arsenal GesmbH, raum \& kommunikation $\mathrm{GmbH}$, Vienna University of Technology, Energieinstitut der Wirtschaft $\mathrm{GmbH}$, and Austrian Institute of Technology GmbH (2011). Smart City Wien: Short Report. Climate and Energy Fund. http://www.smartcities.at/assets/Projektberichte/Endbericht-Kurzfassung/EndberichtK11NE2F00030-Wien-kurz-dt-engl-v1.0.pdf. Accessed 01.09.2016.

City of Vienna, 3420 Aspern Development AG, Siemens AG Österreich, Österreichisches Forschungs- und Prüfzentrum Arsenal GesmbH, raum \& kommunikation $\mathrm{GmbH}$, Vienna University of Technology, Energieinstitut der Wirtschaft $\mathrm{GmbH}$, and Austrian Institute of Technology GmbH (2013). Smart City Wien: Vision 2050, Roadmap for 2020 and Beyond, Action Plan for 2012-15. https://www.wien.gv.at/stadtentwicklung/studien/pdf/b008218.pdf. Accessed 01.09.2016.

CLUE Project Partners (2014). Practices, Tools and Policies: European Cities Moving Towards Climate Neutrality. Report. http://www.clue-project.eu/getfile.ashx?cid=503736\&cc=3\&refid=18. Accessed 10.03.2016.

Cocchia, A. (2014). Smart and Digital City: A Systematic Literature Review. In R. P. Dameri, and C. RosenthalSabroux (Eds.), Smart City: How to Create Public and Economic Value with High Technology in Urban Space (pp. 13-43). Berlin: Springer.

Cohen, B. (2012a). The 10 Smartest Cities on the Planet. Fast Company. http://www.fastcoexist.com/1679127/thetop-10-smart-cities-on-the-planet. Accessed 02.10.2014.

Cohen, B. (2012b). The 10 Smartest European Cities. Fast Company. http://www.fastcoexist.com/1680856/thetop-10-smartest-european-cities. Accessed 02.08.2014.

Cohen, B. (2014). The 10 Smartest Cities in Europe. Fast Company. http://www.fastcoexist.com/3024721/the-10smartest-cities-in-europe?partner=rss\&utm_source=feedburner\&utm_medium=feed\&utm_campaign=Feed\%3A+fastcoexist\%2Ffeed+\%28Co.Exist\%29. Accessed 02.08.2014.

Coletta, C., Heaphy, L., and Kitchin, R. (2017). From the Accidental to Articulated Smart City: The Creation and Work of Smart Dublin. Working paper. Maynooth University. https://osf.io/preprints/socarxiv/93ga5. Accessed 12.09.2017.

Concilio, G., and Rizzo, F. (Eds.) (2016). Human Smart Cities: Rethinking the Interplay Between Design and Planning. Berlin: Springer.

Concilio, G., Molinari, F., and Morelli, N. (2017). Empowering Citizens with Open Data by Urban Hackathons. In 2017 Conference for E-Democracy and Open Government (CeDEM), Krems, 17-19 May 2017 (pp. 125-134). Piscataway, NJ: Institute of Electrical and Electronics Engineers (IEEE).

Cosgrove, M., Harthoorn, W., Hogan, J., Jabbar, R., Kehoe, M., Meegan, J., and Nesbitt, P. (2011). Smarter Cities Series: Introducing the IBM City Operations and Management Solution. IBM Corporation. http://www.redbooks.ibm.com/redpapers/pdfs/redp4734.pdf. Accessed 14.09.2012.

Cowley, R., Joss, S., and Dayot, Y. (2017). The Smart City and Its Publics: Insights from Across Six UK Cities. Urban Research \& Practice, doi:http://dx.doi.org/10.1080/17535069.2017.1293150. 
Creswell, J. W. (2009). Research Design: Qualitative, Quantitative, and Mixed Methods Approaches. 3 ed. Thousand Oaks, CA: SAGE Publications.

Cugurullo, F. (2013). How to Build a Sandcastle: An Analysis of the Genesis and Development of Masdar City. Journal of Urban Technology, 20(1), 23-37.

Cugurullo, F. (2016). Urban Eco-modernisation and the Policy Context of New Eco-city Projects: Where Masdar City Fails and Why. Urban Studies, 53(11), 2417-2433.

Curwell, S., Deakin, M., Cooper, I., Paskaleva-Shapira, K., Ravetz, J., and Babicki, D. (2005). Citizens' Expectations of Information Cities: Implications for Urban Planning and Design. Building Research \& Information, 33(1), 55-66.

Dameri, R. P. (2013). Searching for Smart City Definition: A Comprehensive Proposal. International Journal of Computers \& Technology, 11(5), 2544-2551.

Dameri, R. P. (2014). Comparing Smart and Digital City: Initiatives and Strategies in Amsterdam and Genoa. Are They Digital And/or Smart?. In R. P. Dameri, and C. Rosenthal-Sabroux (Eds.), Smart City: How to Create Public and Economic Value with High Technology in Urban Space (pp. 45-88). Berlin: Springer.

Dameri, R. P. (2017). Smart City Implementation: Creating Economic and Public Value in Innovative Urban Systems. Cham: Springer.

Datta, A. (2015). New Urban Utopias of Postcolonial India: Entrepreneurial Urbanization in Dholera Smart City, Gujarat. Dialogues in Human Geography, 5(1), 3-22.

Deakin, M. (2014a). Smart Cities: The State-of-the-art and Governance Challenge. Triple Helix, 1(7), 1-16.

Deakin, M. (Ed.) (2014b). Smart Cities: Governing, Modelling and Analysing the Transition. New York City, NY: Routledge.

Deakin, M., and Al Wear, H. (2011). From Intelligent to Smart Cities. Intelligent Buildings International, 3(3), 140152.

Deakin, M., and Allwinkle, S. (2007). Urban Regeneration and Sustainable Communities: The Role of Networks, Innovation, and Creativity in Building Successful Partnerships. Journal of Urban Technology, 14(1), 77-91.

Deakin, M., and Leydesdorff, L. (2014). The Triple Helix Model of Smart Cities: A Neo-Evolutionary Perspective. In M. Deakin (Ed.), Smart Cities: Governing, Modelling and Analyzing the Transition (pp. 134-149). New York, NY: Routledge.

Deambrogio, E. (2013). Towards Torino Smart City. City of Turin. https://www.itu.int/en/ITU-T/climatechange/symposia/201305/Documents/info/Presentations/s7p6-ElenaDeambrogio.pdf. Accessed 05.03.2016.

Dirks, S., and Keeling, M. (2009). A Vision of Smarter Cities: How Cities Can Lead the Way into a Prosperous and Sustainable Future. Executive report. IBM Corporation. http://www-03.ibm.com/press/attachments/IBV_Smarter_Cities_-_Final.pdf. Accessed 03.02.2012.

Dirks, S., Gurdgiev, C., and Keeling, M. (2010). Smarter Cities for Smarter Growth: How Cities Can Optimize Their Systems for the Talent-based Economy. Executive report. IBM Corporation. http://public.dhe.ibm.com/common/ssi/ecm/en/gbe03348usen/GBE03348USEN.PDF. Accessed 03.02.2012.

Dirks, S., Keeling, M., and Dencik, J. (2009). How Smart Is Your City: Helping Cities Measure Progress. Executive report. IBM Corporation. http://public.dhe.ibm.com/common/ssi/ecm/en/gbe03248usen/GBE03248USEN.PDF. Accessed 06.06.2014.

Eisenhardt, K. M. (1989). Building Theories from Case Study Research. Academy of Management Review, 14(4), 532-550.

Eisenhardt, K. M., and Graebner, M. E. (2007). Theory Building from Cases: Opportunities and Challenges. Academy of Management Journal, 50(1), 25-32.

Ersoy, A. (2017). Smart Cities as a Mechanism Towards a Broader Understanding of Infrastructure Interdependencies. Regional Studies, Regional Science, 4(1), 1-6.

Estevez, E., Vasco Lopes, N., and Janowski, T. (2016). Smart Sustainable Cities - Reconnaissance Study. United Nations University and International Development Research Center (IDRC). http://collections.unu.edu/eserv/UNU:5825/Smart_Sustainable_Cities_v2final.pdf. Accessed 08.10.2017.

Etzkowitz, H., and Leydesdorff, L. (2000). The Dynamics of Innovation: From National Systems and "Mode 2" to a Triple Helix of University-industry-government Relations. Research Policy, 29(2), 109-123.

European Commission (2009a). Communication from the Commission to the European Parliament, the Council, the European Economic and Social Committee and the Committee of the Regions on Mobilising Information and Communication Technologies to Facilitate the Transition to An Energy Efficient, Low-carbon Economy. COM(2009) 111 final. European Commission. http://ec.europa.eu/information_society/activities/sustainable_growth/docs/com_2009_111/com2009-111-en.pdf. Accessed 02.02.2014.

European Commission (2009b). Communication from the Commission to the European Parliament, the Council, the European Economic and Social Committee and the Committee of the Regions. Investing in the Development of Low Carbon Technologies (SET-Plan). COM(2009) 519 final. European Commission. http://eur-lex.europa.eu/legal-content/IT/TXT/PDF/?uri=CELEX:52009DC0519\&from=EN. Accessed 02.02.2014.

European Commission (2011). Call FP7-ENERGY-SMARTCITIES-2012. Call fiche. European Commission. https://ec.europa.eu/research/participants/portal/doc/call/fp7/fp7-energy-smartcities-2012/31559-fiche_fp7-energy-2012-smartcities_en.pdf. Accessed 10.02.2016.

European Commission (2012a). Call FP7-SMARTCITIES-2013. European Commission. https://ec.europa.eu/research/participants/portal/doc/call/fp7/fp7-smartcities-2013/32801-call_fiche_fp7-smartcities-2013_en.pdf. Accessed 10.02.2016.

European Commission (2012b). Communication from the Commission: Smart Cities and Communities - European 
Innovation Partnership. C(2012) 4701 final. European Commission. http://eur-lex.europa.eu/legal-content/IT/TXT/PDF/?uri=CELEX:52009DC0519\&from=EN. Accessed 02.02.2014.

European Commission (2014a). Barcelona Is "iCapital" of Europe. Press release. European Commission. http://europa.eu/rapid/press-release_IP-14-239_en.htm?locale=en. Accessed 13.03.2014.

European Commission (2014b). Research and Innovation: Food and Nutrition Security / Sustainable Agriculture. European Commission - Directorate General Development and Cooperation. https://ec.europa.eu/europeaid/sites/devco/files/guide-approach-paper-ar4d-2014_en_0.pdf. Accessed 07.10.2013.

European Commission (2016a). Horizon 2020 Work Programme 2016-2017: Cross-cutting Activities (Focus Areas). European Commission Decision C(2016)4614. European Commission. http://ec.europa.eu/research/participants/data/ref/h2020/wp/2016_2017/main/h2020-wp1617-focus_en.pdf. Accessed 20.01.2017.

European Commission (2016b). Urban Agenda for the EU: Pact of Amsterdam. European Commission. https://ec.europa.eu/futurium/en/system/files/ged/pact-of-amsterdam_en.pdf. Accessed 10.12.2017.

European Innovation Partnership on Smart Cities and Communities (2013). European Innovation Partnership on Smart Cities and Communities Strategic Implementation Plan. European Commission. http://ec.europa.eu/eip/smartcities/files/sip_final_en.pdf. Accessed 28.03.2017.

Exner, J. (2015). Smart Cities - Field of Application for Planning Support Systems in the 21st Century?. In Proceedings Computers in Urban Planning and Urban Management 2015, Cambridge, MA, 7-10 July 2015 Cambridge, MA: Massachusetts Institute of Technology.

Fietkiewicz, K. J., and Stock, W. G. (2015). How Smart Are Japanese Cities? An Empirical Investigation of Infrastructures and Governmental Programs in Tokyo, Yokohama, Osaka and Kyoto. In T. X. Bui, and R. H. Sprague (Eds.), Proceedings of the 48th Hawaii International Conference on System Sciences (HICSS), Kauai, HI, 5-8 January 2015 (pp. 2345-2354). Piscataway, NJ: Institute of Electrical and Electronics Engineers.

Food and Agriculture Organization (2013). FAO Strategy for Partnerships with Civil Society Organizations. Food and Agriculture Organization. http://www.fao.org/3/a-i3443e.pdf. Accessed 27.05.2017.

Forum Virium Helsinki (2014). Forum Virium Helsinki. Presentation. Forum Virium Helsinki. https://forumvirium.fi/en/introduction/materials. Accessed 05.09.2016.

Forum Virium Helsinki (2015). Building an Open City. Forum Virium Helsinki. https://forumvirium.fi/en/introduction/materials. Accessed 05.09.2016.

Fruchterman, T. M. J., and Reingold, E. M. (1991). Graph Drawing by Force-directed Placement. Software-practice and experience, 21(11), 1129-1164.

Fullard, A. (2016). Information Communication Technology and Digital Strategy 2016-2021. City of Birmingham. https://www.birmingham.gov.uk/download/downloads/id/5029/birmingham_city_council_ict_and_digital_strategy_2016-2021.pdf. Accessed 20.12.2017.

Future Cities Catapult, and Arup (2017). Smart City Strategies: A Global Review. Future Cities Catapult. http://futurecities.catapult.org.uk/wp-content/uploads/2017/11/GRSCS-Final-Report.pdf. Accessed 12.12.2017.

Gardner, N., and Hespanhol, L. (2017). SMLXL: Scaling the Smart City, From Metropolis to Individual. City, Culture and Society, doi:https://doi.org/10.1016/j.ccs.2017.06.006.

George, A. L., and Bennett, A. (2005). Case Studies and Theory Development in the Social Sciences. Cambridge, MA: MIT Press.

Gibbs, G. R. (2007). Analysing Qualitative Data. Thousand Oaks, CA: SAGE Publications.

Gibson, J., Robinson, M., and Cain, S. (2015). City Initiatives for Technology, Innovation and Entrepreneurship:

A Resource for City Leadership. Nesta, Accenture and Future Cities Catapult. http://citie.org/assets/uploads/2015/04/CITIE_Report_2015.pdf. Accessed 10.08.2016.

Giffinger, R., Ferter, C., Kramar, H., Kalasek, R., Pichler-Milanović, N., and Meijers, E. (2007). Smart Cities: Ranking of European Medium-sized Cities. Research report. Vienna University of Technology - Centre of Regional Science (SRF). http://www.smart-cities.eu/download/smart_cities_final_report.pdf. Accessed 09.05.2012.

Gooch, D., Wolff, A., Kortuem, G., and Brown, R. (2015). Reimagining the Role of Citizens in Smart City Projects. In UbiComp/ISWC'15 Adjunct: Adjunct Proceedings of the 2015 ACM International Joint Conference on Pervasive and Ubiquitous Computing and Proceedings of the 2015 ACM International Symposium on Wearable Computers, Osaka, 7-11 September 2015 (pp. 1587-1594). New York, NY: ACM.

Grimaldi, D., and Fernandez, V. (2017). The Alignment of University Curricula with the Building of a Smart City: A Case Study from Barcelona. Technological Forecasting and Social Change, 123, 298-306.

Grossi, G., and Pianezzi, D. (2017). Smart Cities: Utopia or Neoliberal Ideology?. Cities: The International Journal of Urban Policy and Planning, 69, 79-85.

Gupta, K., and Hall, R. P. (2017). The Indian Perspective of Smart Cities. In Proceedings of the 2017 Smart City Symposium Prague (SCSP), Prague, 25-26 May 2017. Piscataway, NJ: Institute of Electrical and Electronics Engineers.

Harrison, C., Eckman, B., Hamilton, R., Hartswick, P., Kalagnanam, J., Paraszczak, J., and Williams, P. (2010). Foundations for Smarter Cities. IBM Journal of Research and Development, 54(4), 1-16.

Harrison, C., Paraszczak, J., and Williams, R. P. (2011). Preface: Smarter Cities. IBM Journal of Research and Development, 55(1-2), 1-5.

Hartmann, S., Hlava, P., Tiede, L., Kintisch, M., Mollay, U., Schremmer, C., Brajovic, T., Breitfuss, A., Leitner, S., Brus, T., Weninger, K., and Kalasek, R. (2015). Transformation Agenda Vienna. Report. http://urbantransform.eu/wp-content/uploads/sites/2/2015/07/D2.2 Transformation-Agenda-Vienna.pdf. Accessed 12.05.2016.

Hemis, H., Schmid, W., Gigler, U., den Boogert, G., Muller, S., Stock, H., Uuong, D., Emery, S., Meskel, E., Weber, 
P., Jaeger, J., Ljungqvist, L., Geier, S., Olszak, A., Wróblewski, M., Santman, M., Malnar Neralić, S., Mornar, N., Matasović, M., and Zidar, M. (2017). Integrating Energy in Urban Planning Processes - Insights From Amsterdam/Zaanstad, Berlin, Paris, Stockholm, Vienna, Warsaw and Zagreb. Report. http://www.urbanlearning.eu/fileadmin/user_upload/documents/D4-2_Synthesis-report_upgraded_processes_final_170807.pdf. Accessed 05.09.2017.

Henriquez, L. (2015). The Amsterdam Smart Citizens Lab: Towards Community Driven Data Collection. Waag Society and AMS Institute. https://waag.org/sites/waag/files/public/media/publicaties/amsterdam-smart-citizenlab-publicatie.pdf. Accessed 10.11.2016.

Hofstetter, K., and Vogl, A. (2011). Smart City Wien: Vienna's Stepping Stone Into the European Future of Technology and Climate. In M. Schrenk, V. V. Popovich, and P. Zeile (Eds.), REAL CORP 2011. Change for Stability: Lifecycles of Cities and Regions. The Role and Possibilities of Foresighted Planning in Transformation Processes. Proceedings of 16th International Conference on Urban Planning, Regional Development and Information Society, Essen, 18-20 May 2011 (pp. 1373-1382). Schwechat: Competence Center of Urban and Regional Planning (CORP).

Hollands, R. G. (2008). Will the Real Smart City Please Stand Up?. City: analysis of urban trends, culture, theory, policy, action, 12(3), 303-320.

Hollands, R. G. (2015). Critical Interventions into the Corporate Smart City. Cambridge Journal of Regions, Economy and Society, 8(1), 61-77.

Hollands, R. G. (2016). Beyond the Corporate Smart City? Glimpses of Other Possibilities of Smartness. In S. Marvin, A. Luque-Ayala, and C. McFarlane (Eds.), Smart Urbanism: Utopian Vision or False Dawn? (pp. 168184). New York City, NY: Routledge.

Hutter, B. M., and O'Mahony, J. (2004). The Role of Civil Society Organisations in Regulating Business. Discussion paper. London School of Economics and Political Science. http://www.Ise.ac.uk/accounting/CARR/pdf/DPs/Disspaper26.pdf. Accessed 24.08.2017.

IDC (2016). IDC Smart Cities Österreich 2016 Studie. IDC. http://idc-austria.at/de/research/local-studies. Accessed 10.08.2017.

Ielite, I., Olevsky, G., and Safiulins, T. (2015). Identification and Prioritization of Stakeholders in the Planning Process of Sustainable Development of the Smart City. In 2015 IEEE Seventh International Conference on Intelligent Computing and Information Systems (ICICIS'15), Cairo, 12-14 December 2015 (pp. 251-257). Piscataway, $\mathrm{NJ}$ : Institute of Electrical and Electronics Engineers (IEEE).

Irani, L. (2015). Hackathons and the Making of Entrepreneurial Citizenship. Science, Technology, and Human Values, 40(5), 799-824.

Johnson, P., and Robinson, P. (2014). Civic Hackathons: Innovation, Procurement, or Civic Engagement?. Review of Policy Research, 31(4), 349-357.

Katz, J. S., and Ruano, J. (2011). Smarter Cities Series: Understanding the IBM Approach to Energy Innovation. IBM Corporation. http://www.redbooks.ibm.com/redpapers/pdfs/redp4739.pdf. Accessed 14.09.2012.

Kehoe, M., Cosgrove, M., De Gennaro, S., Harrison, C., Harthoorn, W., Hogan, J., Meegan, J., Nesbitt, P., and Peters, C. (2011). Smarter Cities Series: A Foundation for Understanding IBM Smarter Cities. IBM Corporation. http://www.redbooks.ibm.com/redpapers/pdfs/redp4733.pdf. Accessed 14.09.2012.

Kitchin, R. (2014). The Real-time City? Big Data and Smart Urbanism. GeoJournal, 79(1), 1-14.

Kitchin, R. (2015). Making Sense of Smart Cities: Addressing Present Shortcomings. Cambridge Journal of Regions, Economy and Society, 8(1), 131-136.

Kohno, M., Masuyama, Y., Kato, N., and Tobe, A. (2011). Hitachi's Smart City Solutions for New Era of Urban Development. Hitachi Review, 60(2), 79-88.

Komninos, N. (2011). Intelligent Cities: Variable Geometries of Spatial Intelligence. Intelligent building international, 3(3), 172-188.

Komninos, N. (2014). The Age of Intelligent Cities: Smart Environments and Innovation-for-all Strategies. New York City, NY: Routledge.

Komninos, N., and Mora, L. (2018). Exploring the Big Picture of Smart City Research. Scienze Regionali: Italian Journal of Regional Science, 1(2018), 15-38

Komssi, M., Pichlis, D., Raatikainen, M., Kindström, K., and Järvinen, J. (2015). What Are Hackathons For?. IEEE Software, 32(5), 60-67.

Kotkin, J. (2009). The World's Smartest Cities. Forbes. http://www.forbes.com/2009/12/03/infrastructure-economyurban-opinions-columnists-smart-cities-09-joel-kotkin.html. Accessed 05.09.2016.

Kourtit, K., Deakin, M., Caragliu, A., Del Bo, C., Nijkamp, P., Lombardi, P., and Giordano, S. (2014). An Advanced Triple Helix Network Framework for Smart Cities Performance. In M. Deakin (Ed.), Smart Cities: Governing, Modelling and Analyzing the Transition (pp. 196-216). New York, NY: Routledge.

Kurebayashi, T., Masuyama, Y., Morita, K., Taniguchi, N., and Mizuki, F. (2011). Global Initiatives for Smart Urban Development. Hitachi Review, 60(2), 89-93.

Lee, J. H., Phaal, R., and Lee, S. (2013). An Integrated Service-device-technology Roadmap for Smart City Development. Technological Forecasting and Social Change, 80(2), 286-306.

Lee, J., and Hancock, M. G. (2012). Toward a Framework for Smart Cities: A Comparison of Seoul, San Francisco and Amsterdam. Yonsei University and Stanford University. http://iis-db.stanford.edu/evnts/7239/Jung_Hoon_Lee_final.pdf. Accessed 12.06.2014.

Lee, J., Hancock, M. G., and Hu, M. (2014). Towards an Effective Framework for Building Smart Cities: Lessons from Seoul and San Francisco. Technological Forecasting and Social Change, 89, 80-99.

Lee, S. K., Kwon, H. R., Cho, H., Kim, J., and Lee, D. (2016). International Case Studies of Smart Cities: Singapore, 
Republic of Singapore. Discussion paper. Inter-American Development Bank. https://publications.iadb.org/bitstream/handle/11319/7723/International-Case-Studies-of-Smart-Cities-Singapore-Republic-of-Singapore.pdf?sequence=1. Accessed 15.07.2017.

Lerner, J. (2014). Urban Acupuncture: Celebrating Pinpricks of Change That Enrich City Life. Washington, DC: Island Press.

Leydesdorff, L., and Deakin, M. (2011). The Triple-helix Model of Smart Cities: A Neo-Evolutionary Perspective. Journal of Urban Technology, 18(2), 53-63.

Lodato, T. J., and DiSalvo, C. (2016). Issue-oriented Hackathons as Material Participation. new media and society, 18(4), 539-557.

Lombardi, P., Giordano, S., Farouh, H., and Yousef, W. (2012). Modelling the Smart City Performance. Innovation: The European Journal of Social Science Research, 25(2), 137-149.

Luque-Ayala, A., and Marvin, S. (2015). Developing a Critical Understanding of Smart Urbanism?. Urban Studies, 52(12), 2105-2116.

Luque-Ayala, A., McFarlane, C., and Marvin, S. (2014). Smart Urbanism: Cities, Grids and Alternatives?. In M. Hodson, and S. Marvin (Eds.), After Sustainable Cities? (pp. 74-90). New York City, NY: Routeldge.

Manville, C., Cochrane, G., Cave, J., Millard, J., Pederson, J. K., Thaarup, R. K., Liebe, A., Wissner, M., Massink, R., and Kotterink, B. (2014). Mapping Smart City in the EU. European Parliament - Directorate-General for Internal Policies. http://www.europarl.europa.eu/RegData/etudes/etudes/join/2014/507480/IPOLITRE_ET(2014)507480_EN.pdf. Accessed 05.02.2014.

Marguerite, C., Pardo Garcia, N., Haslinger, E., Monteverdi, I., Santicelli, G., and Abdurafikov, R. (2016). CityOpt - Holistic Simulation and Optimization of Energy Systems in Smart Cities: Vienna Demonstrator. Report. http://cityopt.eu/Deliverables/D33.pdf. Accessed 01.02.2017.

Marsal-Llacuna, M., and Segal, M. E. (2016). The Intelligenter Method (I) for Making "smarter" City Projects and Plans. Cities: The International Journal of Urban Policy and Planning, 55, 127-138.

Marsal-Llacuna, M., and Segal, M. E. (2017). The Intelligenter Method (II) for "smarter" Urban Policy-making and Regulation Drafting. Cities: The International Journal of Urban Policy and Planning, 61, 83-95.

Mathie, A., and Cunningham, G. (2003). From Clients to Citizens: Asset-based Community Development as a Strategy for Community-driven Development. Development in Practice, 13(5), 474-486.

Mayangsari, L., and Novani, S. (2015). Multi-stakeholder Co-creation Analysis in Smart City Management: An Experience from Bandung, Indonesia. Procedia Manufacturing, 4, 315-321.

McNeill, D. (2015). Global Firms and Smart Technologies: IBM and the Reduction of Cities. Transactions of the Institute of British Geographers, 40(4), 562-574.

McNeill, D. (2016). IBM and the Visual Formation of Smart Cities. In S. Marvin, A. Luque-Ayala, and C. McFarlane (Eds.), Smart Urbanism: Utopian Vision or False Dawn? (pp. 34-51). New York City, NY: Routledge.

Meijer, A., and Bolivar, M. P. R. (2016). Governing the Smart City: A Review of the Literature on Smart Urban Governance. International Review of Administrative Sciences, 82(2), 392-408.

Moghadam, S. T., Lombardi, P., and Mutani, G. (2017). A Mixed Methodology for Defining a New Spatial Decision Analysis Towards Low Carbon Cities. Procedia Engineering, 198, 375-385.

Mora, L., and Bolici, R. (2016). The Development Process of Smart City Strategies: The Case of Barcelona. In J. Rajaniemi (Ed.), Re-city: Future City - Combining Disciplines (pp. 155-181). Tampere: Juvenes print.

Mora, L., and Bolici, R. (2017). How to Become a Smart City: Learning from Amsterdam. In A. Bisello, D. Vettorato, R. Stephens, and P. Elisei (Eds.), Smart and Sustainable Planning for Cities and Regions: Results of SSPCR 2015 (pp. 251-266). Cham: Springer.

Mora, L., Bolici, R., and Deakin, M. (2017). The First Two Decades of Smart-City Research: A Bibliometric Analysis. Journal of Urban Technology, 24(1), 3-27.

Mora, L., Deakin, M., and Reid, A. (2018a). Combining Co-Citation Clustering and Text-Based Analysis in a Bibliometric Study of Smart City Research [Manuscript submitted for publication].

Mora, L., Deakin, M., and Reid, A. (2018b). Smart City Development Paths: Insights from the First Two Decades of Research. In A. Bisello (Ed.), Smart and Sustainable Planning for Cities and Regions: Results of SSPCR 2017 Cham: Springer.

Mora, L., Deakin, M., Reid, A., and Angelidou, M. (2018c). How to Overcome the Dichotomous Nature of Smart City Research: Proposed Methodology and Results of a Pilot Study [Manuscript submitted for publication].

Muhlmann, P. (2017). Smart City Wien: The City for Life. TINA Vienna GmbH. https://www.publicconsulting.at/fileadmin/user_upload/media/kpcconsulting/Austrian_CC_Workshop_2017/2._P._Muehlmann_Tina_Vienna_Austrian_CC_WS 2017.pdf. Accessed 05.08.2017.

Neirotti, P., De Marco, A., Cagliano, A. C., Mangano, G., and Scorrano, F. (2014). Current Trends in Smart City Initiatives: Some Stylised Facts. Cities: The International Journal of Urban Policy and Planning, 38, 25-36.

Niaros, V. (2016). Introducing a Taxonomy of the "Smart City": Towards a Commons-Oriented Approach?. tripleC, 14(1), 51-61.

Panos, A., Rueda, M. L., Gonçalves, F., Águas, M., Cabral Pinto, F., and García, D. (2016). D7.2 BESOS Evaluation and Assessment. Report. Hypertech. http://cordis.europa.eu/docs/projects/cnect/3/608723/080/deliverables/001-BesosD72EvaluationandAssessment6.pdf. Accessed 10.11.2016.

Paroutis, S., Bennett, M., and Heracleous, L. (2014). A Strategic View on Smart City Technology: The Case of IBM Smarter Cities During a Recession. Technological Forecasting and Social Change, 89, 262-272. 
Patton, M. Q. (2002). Qualitative Research and Evaluation Methods. 3 ed. Thousand Oaks, CA: SAGE Publications.

Paul, A., Cleverley, M., Kerr, W., Marzolini, F., Reade, M., and Russo, S. (2011). Smarter Cities Series: Understanding the IBM Approach to Public Safety. IBM Corporation. http://www.redbooks.ibm.com/redpapers/pdfs/redp4738.pdf. Accessed 14.09.2012.

Pentikousis, K., Zhu, D., and Wang, H. (2011). Network Infrastructure at the Crossroads: The Emergence of Smart Cities. In 2011 15th International Conference on Intelligence in Next Generation Networks, Berlin, 4-7 October 2011 (pp. 109-114). Piscataway, NJ: Institute of Electrical and Electronics Engineers (IEEE).

Pisu, S. (2015). Turin's Smart City Strategy and Projects. Fondazione Torino Wireless. https://www.sas.com/content/dam/SAS/ru_ru/image/events/SAS-Forum-

Russia/Presentation/Intelligence_in_the_Public_Sector/02_Torino_Smart_City_practices_current_projects_an d initiatives-(SFR2015).pdf. Accessed 10.10.2016.

Pollio, A. (2016). Technologies of Austerity Urbanism: The "smart City" Agenda in Italy (2011-2013). Urban Geography, 37(4), 514-534.

Praharaj, S., Han, J. H., and Hawken, S. (2017). Urban Innovation Through Policy Integration: Critical Perspectives From 100 Smart Cities Mission in India. City, Culture and Society, doi:https://doi.org/10.1016/j.ccs.2017.06.004.

Rafiq, G., Talha, B., Pätzold, M., Gato Luis, J., Ripa, G., Carreras, I., Coviello, C., Marzorati, S., Perez Rodriguez, G., Herrero, G., and Desaeger, M. (2013). What's New in Intelligent Transportation Systems? An Overview of European Projects and Initiatives. IEEE Vehicular Technology Magazine, 8(4), 45-69.

Ratti, C., and Townsend, A. (2011). The Social Nexus. Scientific American, September 2011, 42-48.

Reddy Kummitha, R. K., and Crutzen, N. (2017). How Do We Understand Smart Cities? An Evolutionary Perspective. Cities: The International Journal of Urban Policy and Planning, 67, 43-52.

Reviglio, E., Camerano, S., Carriero, A., Del Bufalo, G., Alterio, D., Calderini, M., De Marco, A., Michelucci, F. V., Neirotti, P., and Scorrano, F. (2013). Smart City: Development Projects and Financial Instruments. Report. Cassa depositi e prestiti. http://www.cassaddpp.it/static/upload/mon/monographic-report_smart-city.pdf. Accessed 26.02.2014.

Riva Sanseverino, E., Riva Sanseverino, R., \& Vaccaro, V. (Eds.) (2017). Smart Cities Atlas: Western and Eastern Intelligent Communities. Cham: Springer.

Riva Sanseverino, E., Riva Sanseverino, R., Vaccaro, V., and Zizzo, G. (Eds.) (2014). Smart Rules for Smart Cities: Managing Efficient Cities in Euro-Mediterranean Countries. Cham: Springer.

Robson, C. (1993). Real World Research: A Resource for Users of Social Research Methods in Applied Settings. Hoboken, NJ: John Wiley \& Sons Ltd.

Ruano, J., Chao, T., Hartswick, P., Havers, B., Meegan, J., Wasserkrug, S., and Williams, P. (2011). Smarter Cities Series: Understanding the IBM Approach to Water Management. IBM Corporation. http://www.redbooks.ibm.com/redpapers/pdfs/redp4736.pdf. Accessed 14.09.2012.

Santucci, L., Oele, J., Jordán, R., Valenzuela, B., Barth, B., Stipisic, M. M., Andersson, K., and Wehmer, N. (2011). Are We Building Competitive and Liveable Cities? Guidelines for Developing Eco-efficient and Socially Inclusive Infrastructure. United Nations. http://www.cepal.org/publicaciones/xml/9/52019/Guidelines.pdf. Accessed 10.05.2014.

Schaefer, S., Harrison, C., Lamba, N., and Srikanth, V. (2011). Smarter Cities Series: Understanding the IBM Approach to Traffic Management. IBM Corporation. http://www.redbooks.ibm.com/redpapers/pdfs/redp4737.pdf. Accessed 14.09.2012.

Schaffers, H., Komninos, N., Pallot, M., Aguas, M., Almirall, E., Bakici, T., Barroca, J., Carter, D., Corriou, M., Fernadez, J., Hielkema, H., Kivilehto, A., Nilsson, M., Oliveira, A., Posio, E., Sällström, A., Santoro, R., Senach, B., Torres, I., Tsarchopoulos, P., Trousse, B., Turkama, P., and Lopez Ventura, J. (2012). Smart Cities as Innovation Ecosystems Sustained by the Future Internet. White paper. http://hal.archives-ouvertes.fr/docs/00/76/96/35/PDF/FIREBALL-White-Paper-Final2.pdf. Accessed 24.08.2011.

Schreiner, C. (2016). International Case Studies of Smart Cities: Rio De Janeiro, Brazil. Discussion paper. InterAmerican Development Bank. https://publications.iadb.org/bitstream/handle/11319/7727/International-CaseStudies-of-Smart-Cities-Rio-de-Janeiro-Brazil.pdf?sequence=1\&isAllowed=y. Accessed 15.07.2017.

Schuurman, D., Baccarne, B., De Marez, L., and Mechant, P. (2012). Smart Ideas for Smart Cities: Investigating Crowdsourcing for Generating and Selecting Ideas for ICT Innovation in a City Context. Journal of Theoretical and Applied Electronic Commerce Research, 7(3), 49-62.

Schuurman, D., De Marez, L., and Ballon, P. (2016). The Impact of Living Lab Methodology on Open Innovation Contributions and Outcomes. Technology Innovation Management Review, 6(1), 7-16.

Scuotto, V., Ferraris, A., and Bresciani, S. (2016). Internet of Things. Applications and Challenges in Smart Cities: A Case Study of IBM Smart City Projects. Business Process Management Journal, 22(2), 357-367.

Selada, C. (2017). Smart Cities and the Quadruple Helix Innovation Systems Conceptual Framework: The Case of Portugal. In S. Monteiro, and E. G. Carayannis (Eds.), The Quadruple Innovation Helix Nexus: A Smart Growth Model, Quantitative Empirical Validation and Operationalization for OECD Countries (pp. 211-244). New York City, NY: Palgrave.

Sharma, P., and Rajput, S. (Eds.) (2017). Sustainable Smart Cities in India: Challenges and Future Perspectives. Cham: Springer.

Shin, D. (2007). A Critique of Korean National Information Strategy: Case of National Information Infrastructures. Government Information Quarterly, 24(3), 624-645. 
Shin, D. (2009). Ubiquitous City: Urban Technologies, Urban Infrastructure and Urban Informatics. Journal of Information Science, 35(5), 515-526.

Shin, D. (2010). A Realization of Pervasive Computing: Ubiquitous City. In D. F. Kocaoglu, T. R. Anderson, and T. U. Daim (Eds.), 2010 Proceedings of PICMET '10: Technology Management for Global Economic Growth, Seoul, 18-22 July 2010 (pp. 1-10). Piscataway, NJ: Institute of Electrical and Electronics Engineers (IEEE).

Shwayri, S. T. (2013). A Model Korean Ubiquitous Eco-city? The Politics of Making Songdo. Journal of Urban Technology, 20(1), 39-55.

Siemens AG (2014). Our Future Depends on Intelligent Infrastructures. Siemens AG. https://www.siemens.com/digitalization/public/pdf/siemens-intelligent-infrastructure.pdf. Accessed 06.03.2017.

Singh, S. (2010). Top 20 Mega Trends and Their Impact on Business, Cultures and Society. Frost and Sullivan. http://www.frost.com/prod/servlet/cpo/213016007. Accessed 25.11.2017.

Soderstrom, O., Paasche, T., and Klauser, F. (2014). Smart Cities as Corporate Storytelling. City: analysis of urban trends, culture, theory, policy, action, 18(3), 307-320.

Strauss, A., and Corbin, J. M. (1990). Basics of Qualitative Research: Grounded Theory Procedures and Techniques. Thousand Oaks, CA: SAGE Publications.

Sujata, J., Saksham, S., Godbole, T., and Shreya (2016). Developing Smart Cities: An Integrated Framework. Procedia Computer Science, 93, 902-909.

Tamai, H. (2014). Fujitsu's Approach to Smart Cities. FUJITSU Scientific \& Technical Journal, 50(2), 3-10.

Taylor Buck, N., and While, A. (2017). Competitive Urbanism and the Limits to Smart City Innovation: The UK Future Cities Initiative. Urban Studies, 54(2), 501-519.

The Technopolicy Network (2014). Amsterdam Innovation Motor. The Technopolicy Network. http://technopolicy.net/index.php?option=com_content\&view=article\&id=41\&Itemid=59. Accessed 08.08.2016.

Torres, L., Vicente, P., and Acerete, B. (2006). E-Governance Developments in European Union Cities: Reshaping Government's Relationship with Citizens. Governance: An International Journal of Policy, Administration, and Institutions, 19(2), 277-302.

Townsend, A. (2013). Smart Cities: Big Data, Civic Hackers, and the Quest for a New Utopia. New York City, NY: W.W. Norton \& Company Ltd.

United Nations (1998). Arrangements and Practices for the Interaction of Non-Governmental Organizations in All Activities of the United Nations System. Report of the Secretary-General (A/53/170). United Nations - Department of Economic and Social Affairs. http://www.un.org/documents/ga/docs/53/plenary/a53-170.htm. Accessed 15.05.2017.

United Nations (2015). Transforming Our World: The 2030 Agenda for Sustainable Development. A/RES/70/1. United Nations. https://sustainabledevelopment.un.org/content/documents/21252030\%20Agenda\%20for\%20Sustainable\%20Development\%20web.pdf. Accessed 10.12.2017.

United Nations (2016). Policy Paper 9: Urban Services and Technology. A/CONF.226/PC.3/22. United Nations. http://habitat3.org/wp-content/uploads/Policy-Paper-9-English.pdf. Accessed 10.12.2017.

United Nations (2017). New Urban Agenda. A/RES/71/256. United Nations. http://habitat3.org/wp-content/uploads/NUA-English.pdf. Accessed 10.12.2017.

URBACT Secretariat (2017). URBACT Good Practice Summary: Summary of Good Practice for Heraklion, Crete, Greece. URBACT Secretariat. http://urbact.eu/file/16763/download?token=SvyHrUQW. Accessed 15.08.2017.

van Waart, P., Mulder, I., and de Bont, C. (2016). A Participatory Approach for Envisioning a Smart City. Social Science Computer Review, 34(6), 708-723.

van Winden, W., and van den Buuse, D. (2017). Smart City Pilot Projects: Exploring the Dimensions and Conditions of Scaling Up. Journal of Urban Technology, 24(4), 51-72.

Vanolo, A. (2014). Smartmentality: The Smart City as Disciplinary Strategy. Urban Studies, 51(5), 883-898.

Veeckman, C., and van der Graaf, S. (2014). The City as Living Laboratory: A Playground for the Innovative Development of Smart City Applications. In 2014 International ICE Conference on Engineering, Technology and Innovation (ICE), Bergamo, 23-25 June 2014. Piscataway, NJ: Institute of Electrical and Electronics Engineers (IEEE).

Velthausz, D. (2011). Amsterdam Smart City. Amsterdam Smart City. http://www.slideshare.net/lisa/amsterdamsmart-city-eng-presentation-2-32011-7131457. Accessed 02.08.2016.

Viitanen, J., and Kingston, R. (2014). Smart Cities and Green Growth: Outsourcing Democratic and Environmental Resilience to the Global Technology Sector. Environment and Planning A, 46(4), 803-819.

Walravens, N. (2015). Mobile City Applications for Brussels Citizens: Smart City Trends, Challenges and a Reality Check. Telematics and Informatics, 32(2), 282-299.

Wien Holding GmbH (2012). Quality of Life for Vienna. Wien Holding GmbH. https://www.wienholding.at/tools/uploads/folderbroschueren/WienHolding-English.pdf. Accessed 20.10.206.

Wiener Modellregion, and Climate and Energy Fund (2014). Statusbericht Der Wiener Modellregion "E-Mobility nn Demand“. Report. Wiener Modellregion and Climate and Energy Fund. https://www.klimafonds.gv.at/assets/Uploads/Themenprojekte/Modellregionen/e-mobility-on-demand-Wien/201504-Statusberichtemobility-ondemand-Wienfinal.pdf. Accessed 09.10.2015.

Wiig, A. (2015a). IBM's Smart City as Techno-utopian Policy Mobility. City: analysis of urban trends, culture, theory, policy, action, 19(2-3), 258-273.

Wiig, A. (2015b). The Empty Rhetoric of the Smart City: From Digital Inclusion to Economic Promotion in Philadelphia. Urban Geography, 37(4), 535-553.

World Economic Forum (2013). The Future Role of Civil Society. World Economic Forum. http://www3.weforum.org/docs/WEF_FutureRoleCivilSociety_Report_2013.pdf. Accessed 01.05.2017. 
Yin, R. K. (2009). Case Study Research: Design and Methods. 4 ed. Thousand Oaks, CA: SAGE Publications. Yigitcanlar, T. (2016). Technology and the City: Systems, Applications and Implications. New York City, NY: Routledge.

Yigitcanlar, T., and Lee, S. H. (2014). Korean Ubiquitous-eco-city: A Smart-sustainable Urban Form or a Branding Hoax?. Technological Forecasting \& Social Change, 89, 100-114.

Yoshikawa, Y., Tada, K., Furuya, S., and Koda, K. (2011). Actions for Realizing Next-generation Smart Cities. Hitachi Review, 60(6), 89-93.

Yu, J., Shannon, H., Baumann, A., Schwartz, L., and Bhatt, M. (2016). Slum Upgrading Programs and Disaster Resilience: A Case Study of An Indian 'Smart City'. Procedia Environmental Sciences, 36, 154-161.

Zelt, T., Ibel, J., and Tuncer, F. (2017). THINK ACT: Smart City, Smart Strategy. Roland Berger GmbH. https://www.rolandberger.com/publications/publication_pdf/ta_17_008_smart_cities_online.pdf. Accessed 31.08.2017.

Zygiaris, S. (2013). Smart City Reference Model: Assisting Planners to Conceptualize the Building of Smart City Innovation Ecosystems. Journal of the Knowledge Economy, 4(2), 217-231. 